\title{
Design of a Four-Seat, General Aviation Electric Aircraft
}

\author{
By Priya Chouhan ${ }^{*} \&$ Nikos J. Mourtos ${ }^{+}$
}

\begin{abstract}
Financial and environmental considerations continue to encourage aircraft manufacturers to consider alternate forms of aircraft propulsion. On the financial end, it is the continued rise in aviation fuel prices, as a result of an increasing demand for air travel, and the depletion of fossil fuel resources; on the environmental end, it is concerns related to air pollution and global warming. New aircraft designs are being proposed using electrical and hybrid propulsion systems, as a way of tackling both the financial and environmental challenges associated with the continued use of fossil fuels. While battery capabilities are evolving rapidly, the current state-of-the-art offers an energy density of $\sim 250 \mathrm{Wh} / \mathrm{kg}$. This is sufficient for small, general aviation electric airplanes, with a modest range no more than $200 \mathrm{~km}$. This paper explores the possibility of a medium range $(750 \mathrm{~km})$ electric, four-seat, FAR-23 certifiable general aviation aircraft, assuming an energy density of $1500 \mathrm{Wh} / \mathrm{kg}$, projected to be available in 2025. It presents the conceptual and preliminary design of such an aircraft, which includes weight and performance sizing, fuselage design, wing and high-lift system design, empennage design, landing gear design, weight and balance, stability and control analysis, drag polar estimation, environmental impact and final specifications. The results indicate that such an aircraft is indeed feasible, promising greener general aviation fleets around the world.
\end{abstract}

Keywords: general aviation aircraft, electric aircraft, aircraft design

\section{Introduction}

The main source of energy in aviation today is fossil fuels. As our energy consumption increases exponentially, it leads to a corresponding rise in the demand for these fuels, which will persist in the next few decades. This increased demand causes an increase in fuel prices, which in turn increases the operating cost for airlines, business flying, and general aviation. More importantly, the increasing use of fossil fuels in aviation results in increasing $\mathrm{CO}_{2}$ emissions, as well as increasing noise levels around airports. There are, of course, other ways to produce energy for airplanes, without using fossil fuels. Many of these are currently being explored but they are not, at the moment, close to their full potential (Riddell 2004). Electric aircraft offer lower emissions, lower noise levels during taxing, takeoff and landing, lower operating costs, and improved overall efficiency. This paper explores the possibility of an electric four-seater aircraft, as an alternative to conventional gasoline-powered aircraft.

\footnotetext{
*Research Assistant, Department of Aerospace Engineering, San Jose State University, USA. ${ }^{+}$Professor \& Chair, Department of Aerospace Engineering, San Jose State University, USA.
} 
The paper presents the preliminary design of a four-passenger, electric, general aviation aircraft, with a range of $750 \mathrm{~km}$, a cruise speed of $270 \mathrm{~km} / \mathrm{hr}$ at a cruising altitude of $3,000 \mathrm{~m}$, a takeoff field length of $760 \mathrm{~m}$ and a landing field of $600 \mathrm{~m}$. The main challenge currently associated with electric aircraft is the low specific energy density of the batteries, which results in prohibitive levels of battery weight for typical power requirements. This paper examines possible design solutions that would meet the mission specification of a general aviation aircraft, as described above.

\section{Comparative Study of General Aviation Electric Aircraft}

This section presents a review and comparison of electric general aviation aircraft with a similar mission specification.

\section{Bye Aerospace eFlyer 4}

The eFlyer (Figure 1) was developed from the smaller two seat Bye Aerospace aircraft and is made of composite materials. It features a cantilever low wing with a fixed landing gear, a single engine tractor configuration, with fourseats enclosed under a bubble canopy. The low wing configuration offers greater fuselage volume for passengers, makes it easier to refuel, and easier to retract the landing gear inside the wing. A single electric motor capable of producing $105 \mathrm{~kW}$ $(141 \mathrm{hp})$ is powered by ten batteries, which provide an endurance of four hours.

Figure 1. Bye Aerospace eFlyer 4 (Bye Aerospace 2020)
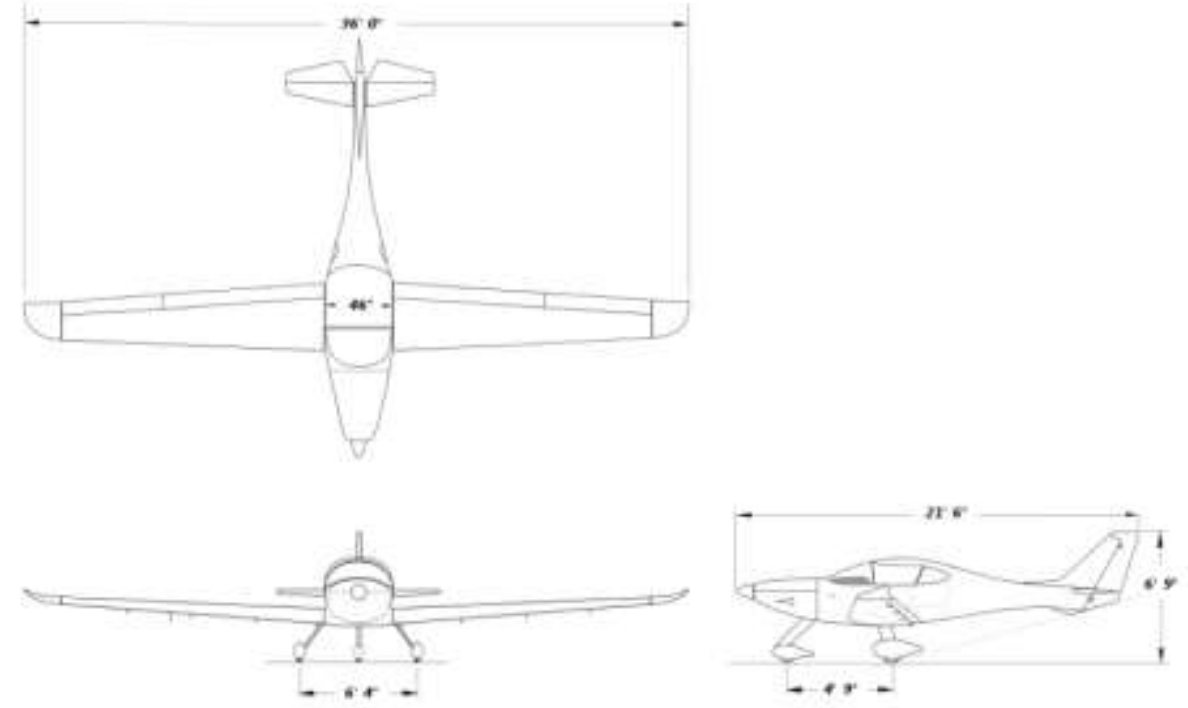


\section{Pipistrel Panthera}

The Pipistrel Panthera (Figure 2) is a lightweight, all-composite, highly efficient, four-seat aircraft, which is currently under development. The Panthera electro features a cantilever low wing arrangement, similar to eFlyer 4 . The fourseater aircraft is powered by a Siemens $200 \mathrm{~kW}$ electric motor and is intended to achieve a $400 \mathrm{~km}$ range with a cruise speed of $218 \mathrm{~km} / \mathrm{hr}$. The T-tail configuration offers a simple design, low empennage weight, better tail efficiencies, while at the same time reducing the interference from the wake of the wing and the propeller slipstream.

Figure 2. Panthera Electro (Panthera 2020)

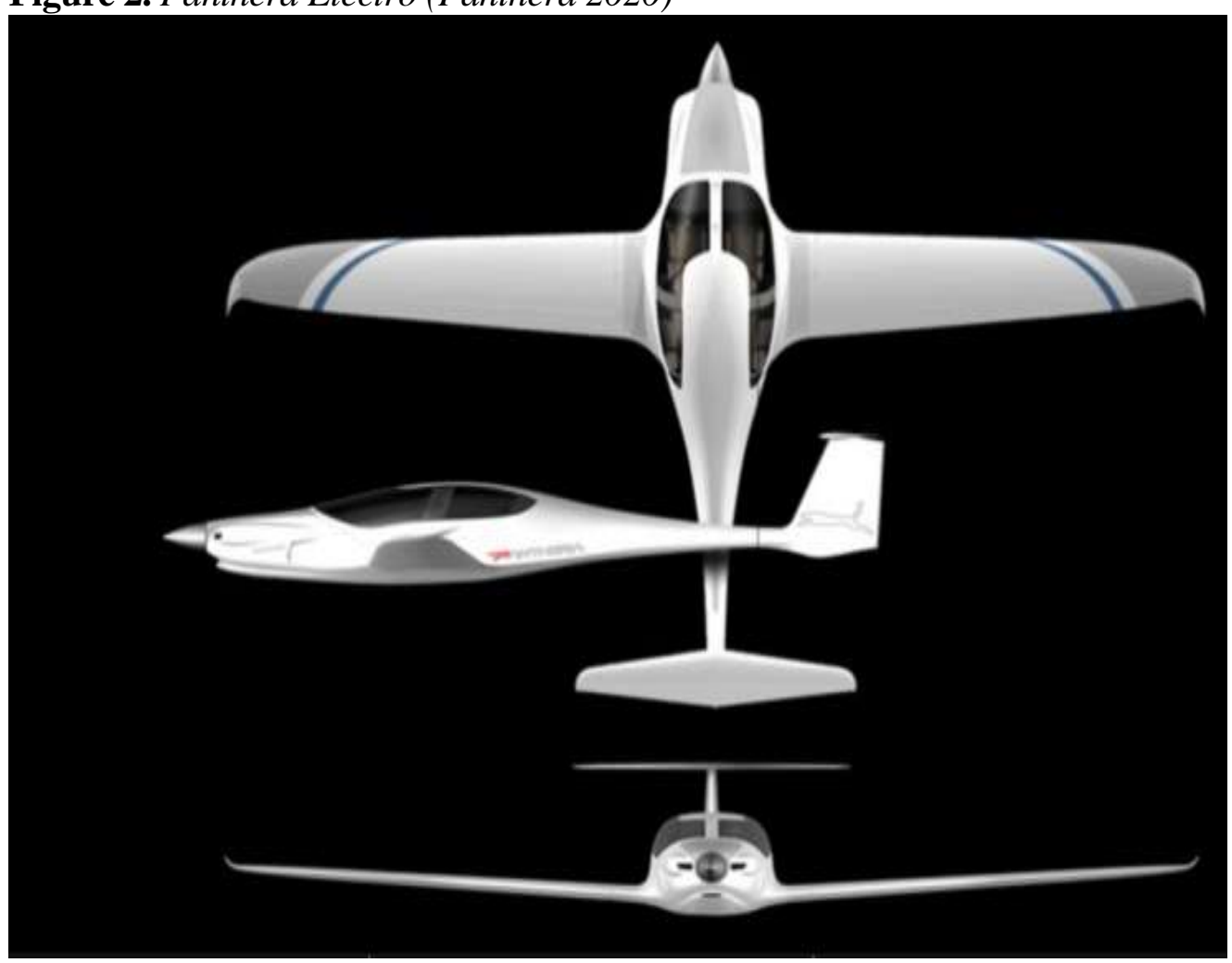

Yuneec International E430

Yuneec E430 (Figure 3) is a two-seater electric aircraft with a cruise speed of $100 \mathrm{~km} / \mathrm{hr}$, designed for commercial production. It has a V-tail and a high wing made of composites with a high aspect ratio. The high wing makes loading and unloading easier, provides better visibility towards the ground and good ground clearance. The aircraft is powered by 3 to 5 packs of Yuneec OEM lithium polymer rechargeable batteries, which provide 2.5 hours endurance. The batteries can be recharged in 3 to 4 hours from a 220 -volt outlet. 
Figure 3. Yuneec E430 (Yuneek 2020)

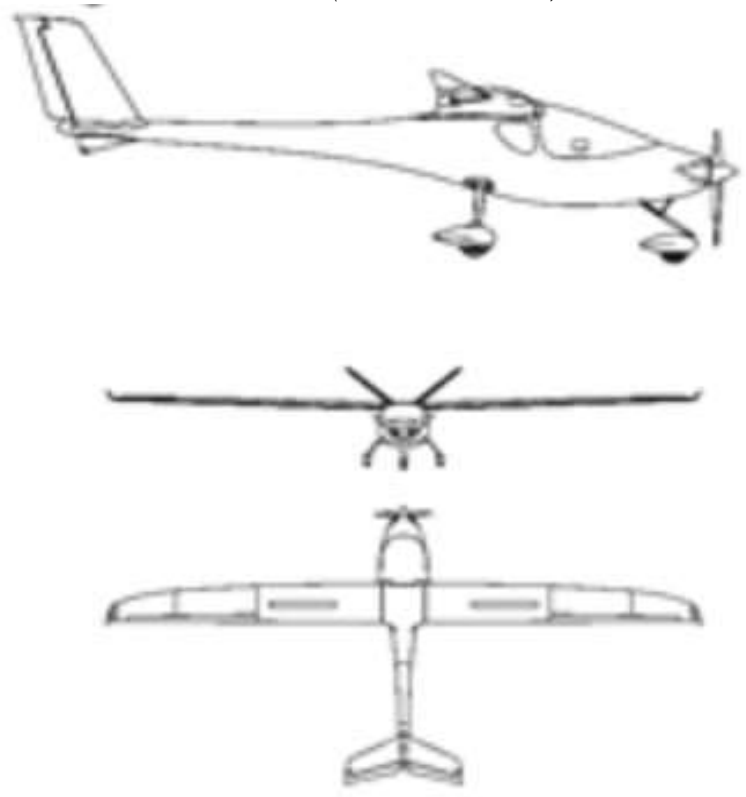

Pipistrel Taurus Electro G2

The Taurus Electro G2 (Figure 4) is a two-seat glider with a range of $600 \mathrm{~km}$. It features a low wing configuration with a T-tail and has replaced the old gasoline-powered engine with a high-performance electric power train and Li-Po batteries.

Figure 4. Taurus Electro G2 (Taurus Electro 2020)
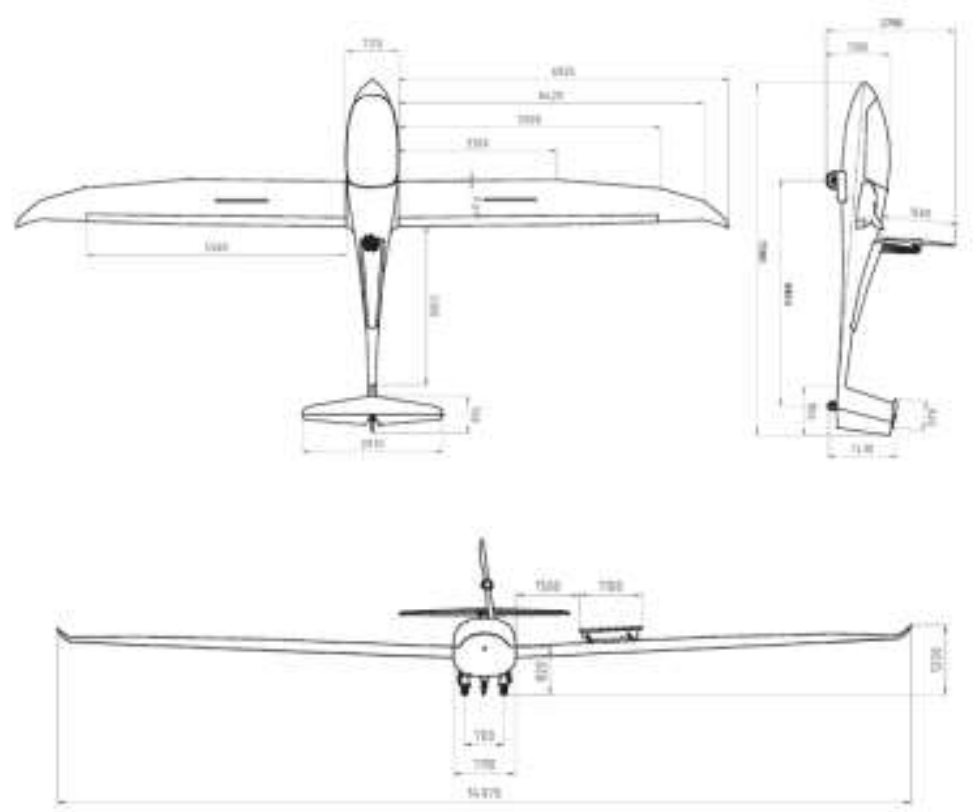


\section{Airbus Vahana}

The Airbus Vahana (Figure 5) is an electric-powered eight propeller VTOL personal air vehicle prototype by Airbus. It is a self-piloted vehicle with a capacity of two passengers for a range of $100 \mathrm{~km}$ cruising at $140 \mathrm{miles} / \mathrm{hr}$. It uses the distributed electric propulsion (DEP) concept on eVTOL aircraft. DEP allows for quickly changing the speed of each propeller independently to compensate for gusty winds, keeping the aircraft stable during flight.

Figure 5. Airbus Vahana (Airbus Vahana 2020)

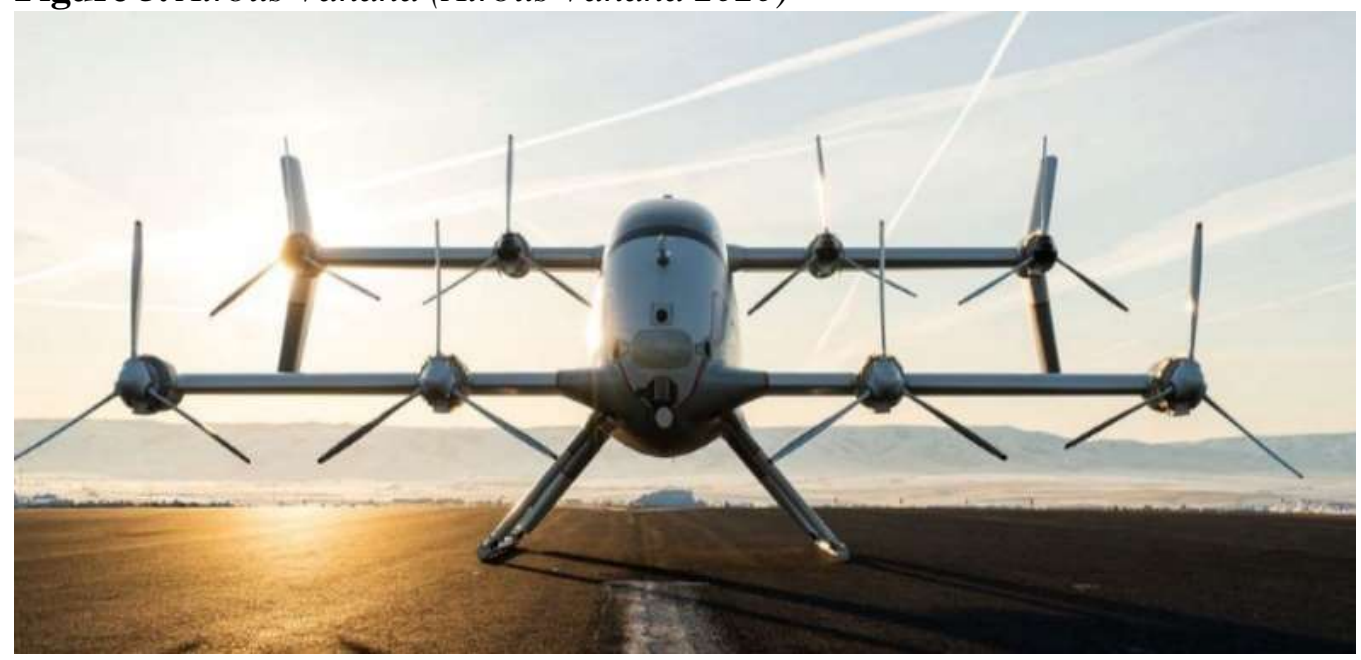

\section{Preliminary Sizing}

The preliminary sizing of the proposed aircraft consists of weight sizing and performance sizing, as described below (Roskam 1985a).

\section{Weight Sizing}

The method below estimates the mission takeoff weight $\left(\mathrm{W}_{\mathrm{TO}}\right)$, the empty weight $\left(\mathrm{W}_{\mathrm{E}}\right)$, and the battery weight $\left(\mathrm{W}_{\mathrm{BAT}}\right)$ of the airplane for the mission specification given in the introduction.

Figure 6 shows a regression plot of takeoff versus empty weight for the airplanes listed in Table 1. 
Table 1. Takeoff and Empty Weight of Similar Electric Airplanes

\begin{tabular}{|l|c|c|}
\hline Aircraft & Takeoff Weight $\left(\mathbf{W}_{\text {TO }}\right)$ lbs & Empty Weight $\left(\mathbf{W}_{\mathbf{E}}\right) \mathbf{l b s}$ \\
\hline $\begin{array}{l}\text { Pipistrel Taurus Electro } \\
\text { G2 (Wikipedia) }\end{array}$ & 1,212 & 674 \\
\hline $\begin{array}{l}\text { Lange Antares 23E } \\
\text { (Wikipedia) }\end{array}$ & 1,873 & 1,124 \\
\hline Extra 330 LE (Wikipedia) & 2,094 & 1,455 \\
\hline $\begin{array}{l}\text { Sunflyer 4 (Bye } \\
\text { Aerospace) }\end{array}$ & 2,700 & 1,900 \\
\hline Airbus Vahana (Airbus) & 1,797 & 1,532 \\
\hline $\begin{array}{l}\text { Pipistrel Panthera } \\
\text { (Wikipedia) }\end{array}$ & 2,645 & 1,764 \\
\hline $\begin{array}{l}\text { Silent 2 Electro } \\
\text { (Alisport Swiss) }\end{array}$ & 6,482 & 4,321 \\
\hline $\begin{array}{l}\text { Electrolight 2 } \\
\text { (Siegler 2011) }\end{array}$ & 6,805 & 4,062 \\
\hline $\begin{array}{l}\text { NASA Scuba Stingray } \\
\text { (Banke 2015) }\end{array}$ & 3,195 & 1,438 \\
\hline
\end{tabular}

Figure 6. Regression Plot of Takeoff versus Empty Weight for the Airplanes in Table 1

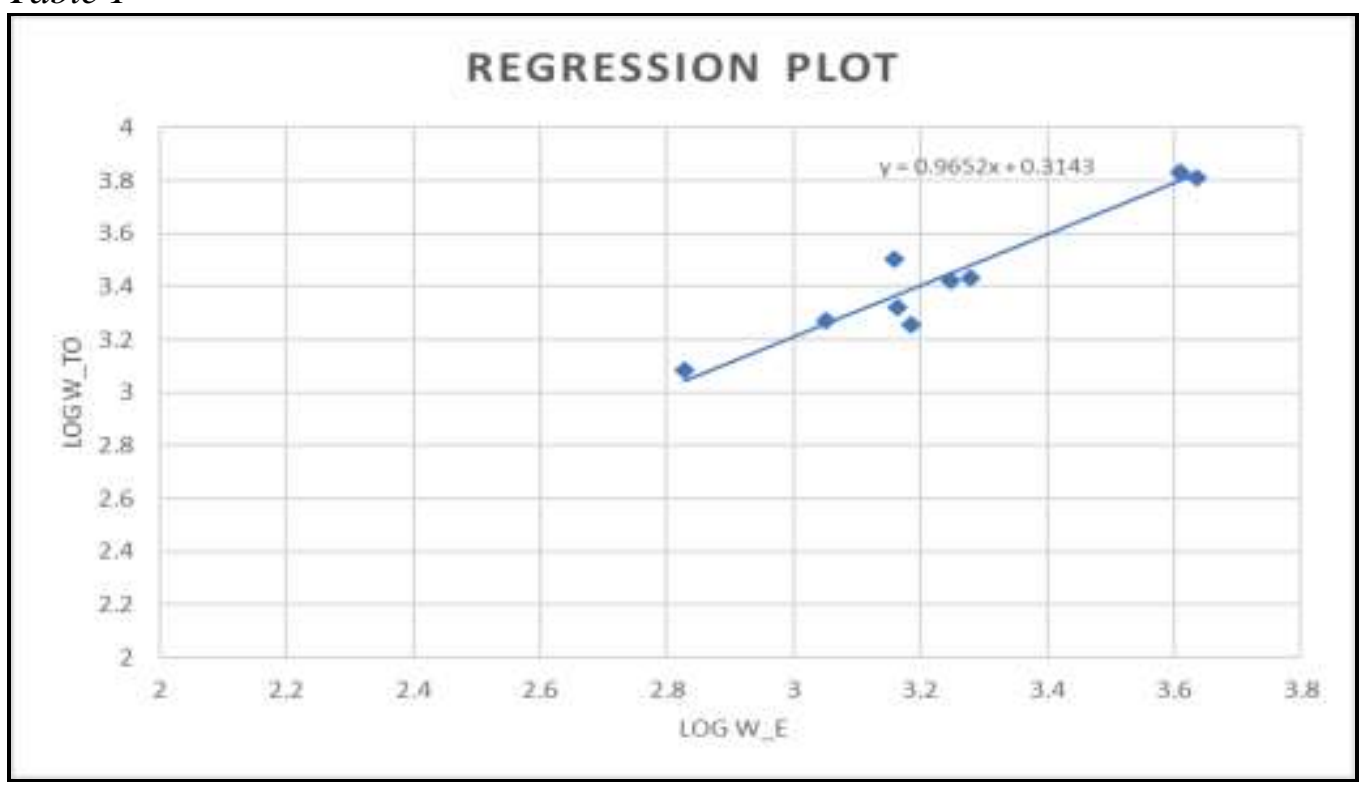

The line in Figure 6 is described by:

$y=0.9652 x+0.3143$

while the relationship between takeoff weight and empty weight is given by:

$\log \mathrm{W}_{\mathrm{TO}}=\mathrm{A}+\mathrm{B} \log \mathrm{W}_{\mathrm{E}}$ 
A comparison of equations (1) and (2) gives the regression coefficients A and $\mathrm{B}$ for the relationship between takeoff and empty weight of electric, general aviation aircraft: $\mathrm{A}=0.3143$ and $\mathrm{B}=0.9652$. The mission weights of the airplane are now calculated as follows.

Payload Weight

Using an average weight of $175 \mathrm{lbs}$ per passenger plus $30 \mathrm{lbs}$ of baggage (Roskam 1985a) the payload weight is $\mathrm{W}_{\mathrm{PL}}=4 \mathrm{x}(175+30)=820 \mathrm{lbs}$.

Battery Weight

Hepperle (2012) gives the following empirical formula for the range of electric aircraft:

$R=E^{*} * \eta *\left(\frac{1}{\mathrm{~g}}\right) *\left(\frac{L}{D}\right) *\left(\frac{W_{B A T}}{W_{T O}}\right)$

Thus, aircraft range depends on lift-to-drag ratio, specific energy density of the battery, total system efficiency, and takeoff weight. Table 2 shows theoretical values of specific energy predicted for the near future (Hepperle 2012).

Table 2. Specific Energy Density for Various Types of Batteries

\begin{tabular}{|l|c|c|}
\hline Battery & Theoretical Value & Expected in the next 5-10 years \\
\hline $\mathrm{Li}-\mathrm{Ion}$ & $390 \mathrm{Wh} / \mathrm{kg}$ & $250 \mathrm{Wh} / \mathrm{kg}$ \\
\hline $\mathrm{Zn}$-air & $1,090 \mathrm{Wh} / \mathrm{kg}$ & $400-500 \mathrm{Wh} / \mathrm{kg}$ \\
\hline $\mathrm{Li}-\mathrm{S}$ & $2,570 \mathrm{Wh} / \mathrm{kg}$ & $500-1,250 \mathrm{Wh} / \mathrm{kg}$ \\
\hline $\mathrm{Li}-\mathrm{O}_{2}$ & $3,500 \mathrm{Wh} / \mathrm{kg}$ & $800-1,750 \mathrm{Wh} / \mathrm{kg}$ \\
\hline
\end{tabular}

Using the data in Table 2, a Li- $\mathrm{O}_{2}$ battery with an energy density of 1500 $\mathrm{Wh} / \mathrm{kg}$ is used in the proposed design. The battery-powered propulsion system offers the highest efficiency compared to conventional turboprop, turbofan and fuel cell systems (Abdel-Hafez 2012). The takeoff weight for the mission is calculated from equation (4) and the weight breakdown is shown in Table 3.

$\mathrm{W}_{\mathrm{TO}}=\mathrm{W}_{\mathrm{E}}+\mathrm{W}_{\mathrm{PL}}+\mathrm{W}_{\mathrm{BAT}}$

Table 3. Summary of Mission Weights

\begin{tabular}{|l|c|}
\hline Take-off weight $\mathrm{W}_{\mathrm{TO}}(\mathrm{lbs})$ & 3,980 \\
\hline Payload weight $\mathrm{W}_{\mathrm{PL}}(\mathrm{lbs})$ & 820 \\
\hline Operating empty weight, $\mathrm{W}_{\mathrm{E}}(\mathrm{lbs})$ & 2,523 \\
\hline Battery Weight, $\mathrm{W}_{\text {Bat }}(\mathrm{lbs})$ & 637 \\
\hline
\end{tabular}


Takeoff Weight Sensitivities

Take-off weight sensitivities are obtained using the regression coefficients A $=0.3143$ and $\mathrm{B}=0.9652$ calculated above and coefficients $\mathrm{C}$ and $\mathrm{D}$ calculated below (Roskam 1985a):

$W_{E}=C W_{T O}-D$

For fully electric aircraft $\mathrm{C}=1$ and

$D=W_{P L}+W_{B A T}=1457 \mathrm{lbs}$

The equations below describe various sensitivities.

Takeoff weight with respect to payload:

$\frac{\delta W_{T O}}{\delta W_{P L}}=\frac{B * W_{T O}}{D-C(1-B) * W_{T O}}$

Takeoff weight with respect to empty weight:

$\frac{\delta W_{T O}}{\delta W_{E}}=\frac{B * W_{T O}}{\operatorname{inv} \cdot \log 10\left[\frac{\log 10 W_{T O}-A}{B}\right]}$

Range with respect to takeoff weight:

$\frac{\delta R}{\delta W_{T O}}=-E^{*} * \eta_{t o t} *(\mathrm{~L} / \mathrm{D}) *(1 / \mathrm{g}) *\left(\frac{\mathrm{W}_{\mathrm{BAT}}}{\mathrm{W}_{\mathrm{TO}}^{2}}\right)$

Range with respect to the lift-to-drag ratio:

$\frac{\delta R}{\delta(L / D)}=\left(1-f_{e}-f_{p}\right) * E^{*} * \eta_{t o t} *(1 / g)$

Range with respect to battery energy density:

$\frac{\delta R}{\delta E^{*}}=\left(1-f_{e}-f_{p}\right) *(L / D) * \eta_{t o t} *(1 / g)$

The sensitivities calculated from the equations above are shown in Table 4 and plotted in Figures 7, 8 and 9. 
Table 4. Takeoff Weight and Range Sensitivities

\begin{tabular}{|c|c|}
\hline Sensitivity Parameters & Sensitivity Values \\
\hline$\delta W_{T O} / \delta W_{P L}$ & $2.92 \mathrm{lbs} / \mathrm{lb}$ \\
\hline$\delta W_{T O} / \delta W_{E}$ & $1.515 \mathrm{lbs} / \mathrm{lb}$ \\
\hline$\delta R / \delta W_{T O}$ & $-0.188 \mathrm{~km} / \mathrm{lb}$ \\
\hline$\delta R / \delta(L / D)$ & $74 \mathrm{~km}$ \\
\hline$\delta R / \delta E^{*}$ & $0.50 \mathrm{~km} / \mathrm{Wh} / \mathrm{kg}$ \\
\hline
\end{tabular}

Figure 7. Takeoff Weight vs. Payload Weight

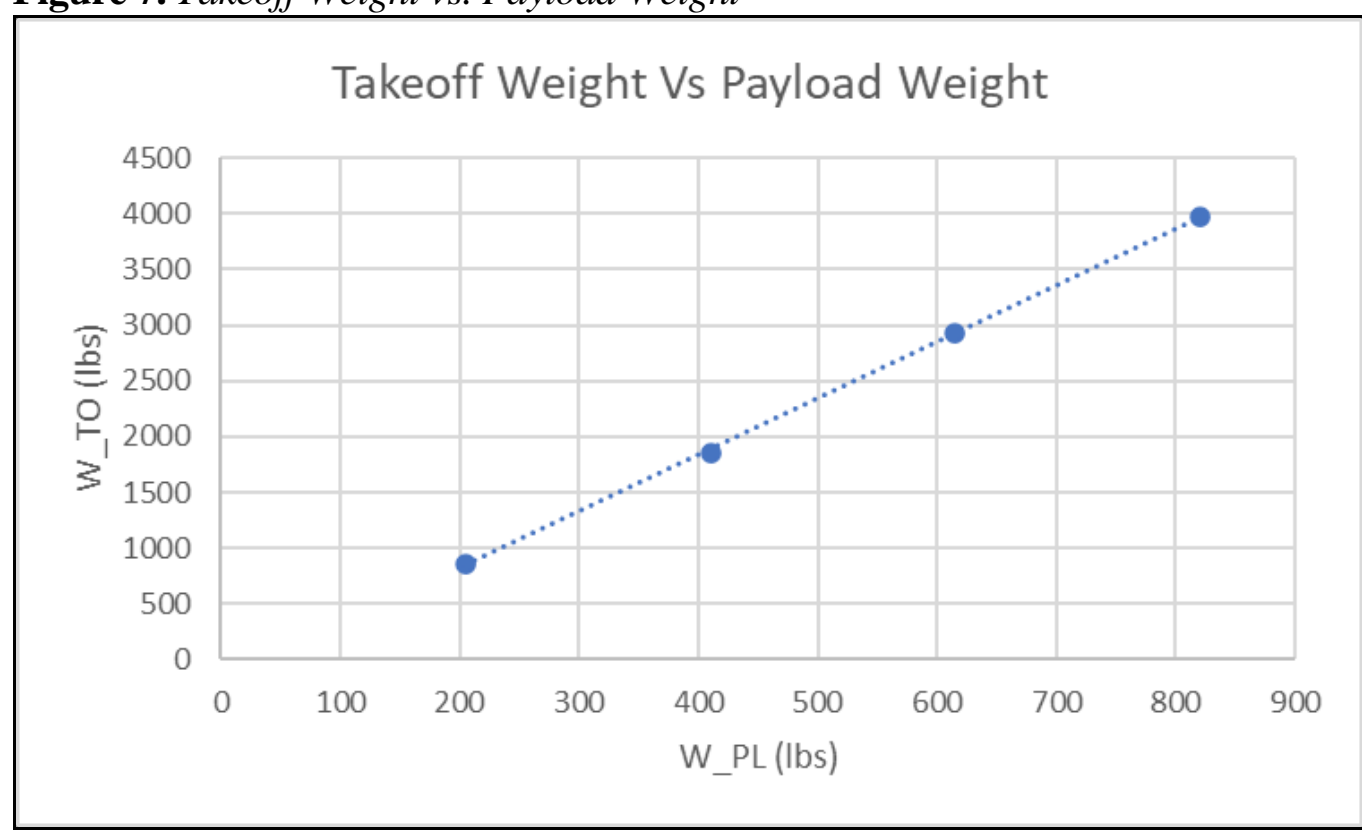

Figure 8. Range vs. Specific Energy Density

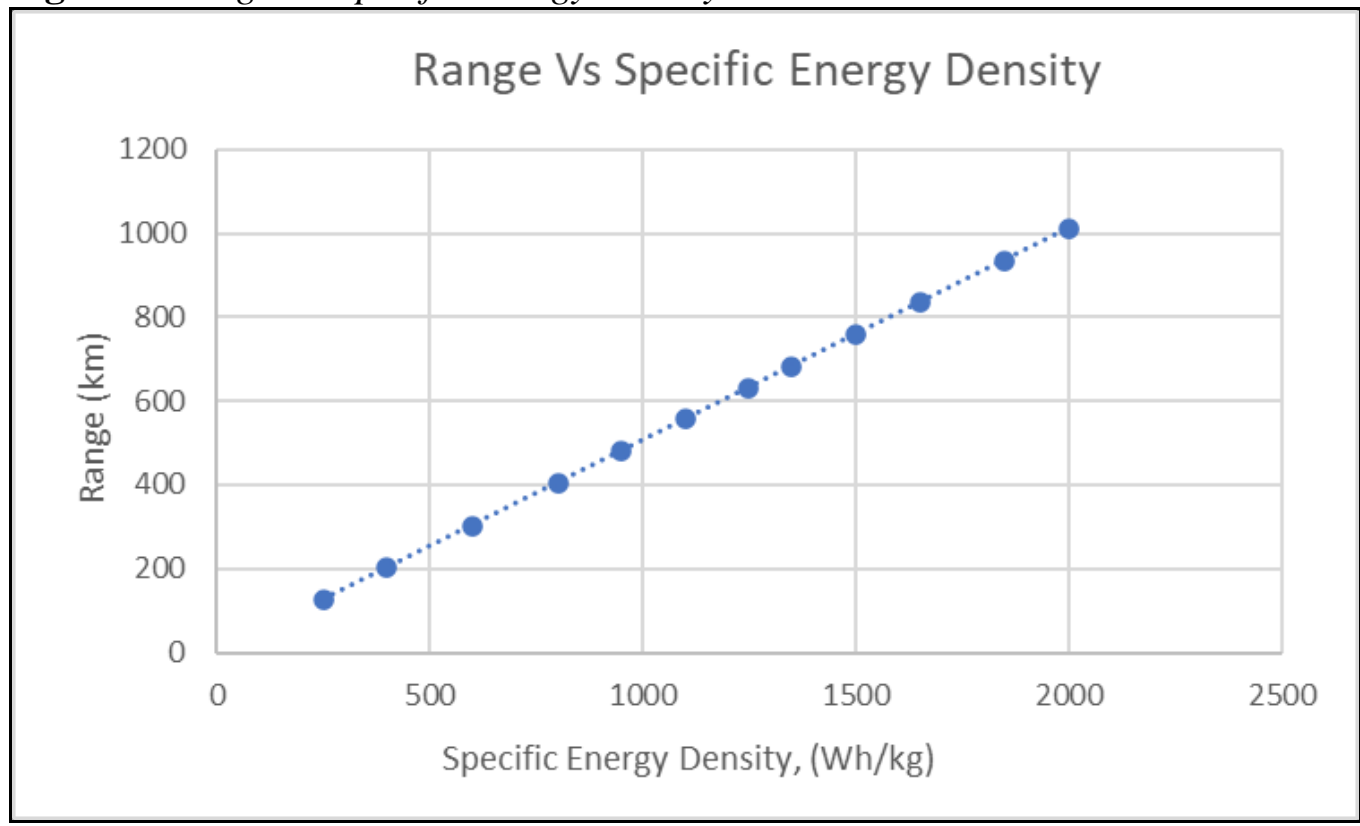


Figure 9. Range vs. Lift-to-Drag Ratio

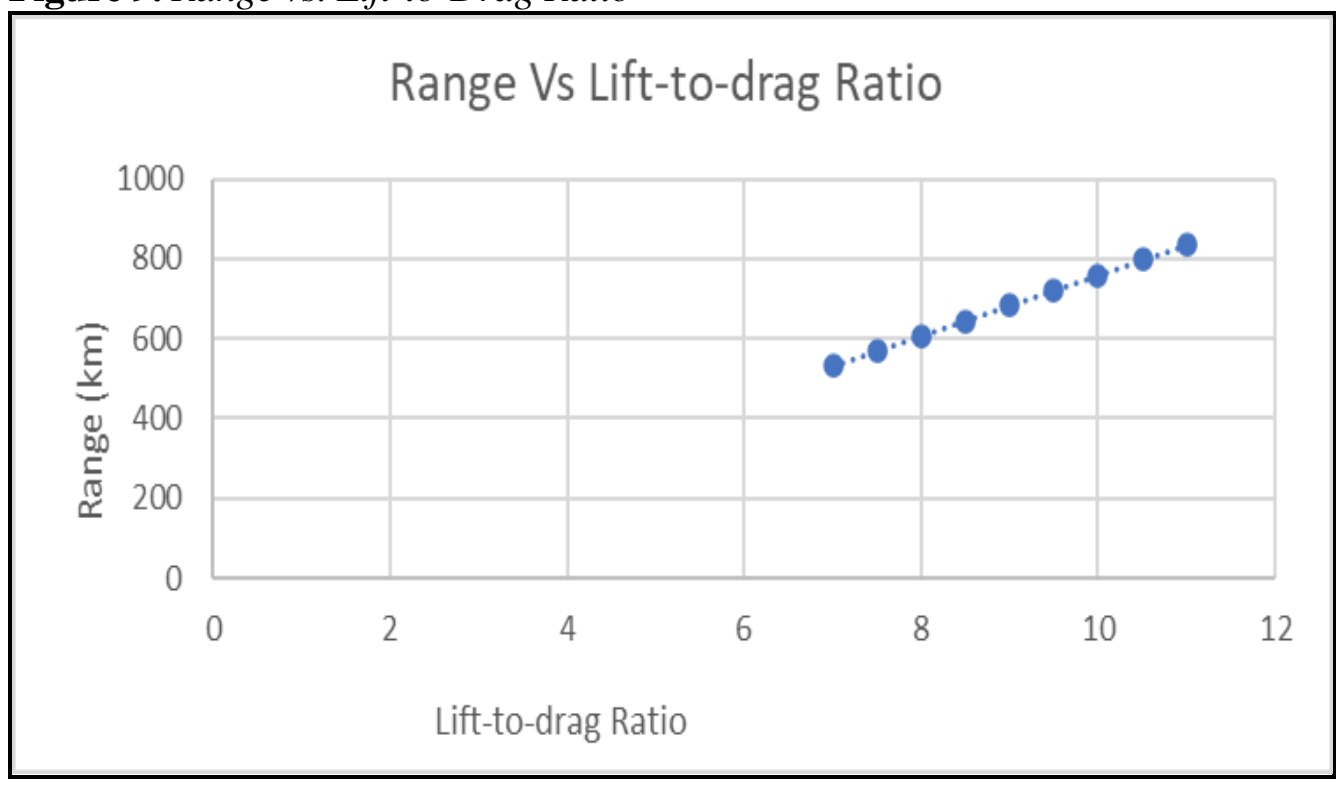

As expected, range depends strongly on the lift-to-drag ratio but also on the specific energy density of the batteries. This is because the takeoff weight of electric aircraft tends to be higher than conventional aircraft due to the weight of the batteries. Hence, improving battery energy density is paramount in helping increase the range of electric aircraft.

\section{Performance Sizing}

The proposed aircraft has a takeoff weight less than 6,000 lbs, hence it falls under the FAR-23 certification regulations. A performance constraint analysis is used to determine the design point of the aircraft, namely the combination of wing area and power required to meet all the mission and FAR 23 requirements. Each requirement is plotted as a relationship between wing loading (W/S) and power loading (W/P), as shown in Figure 11. To meet takeoff and landing requirements an assumption must be made about the maximum lift coefficient of the aircraft in each of the two configurations. The matching graph of the aircraft is presented in Figures 11 and 12.

\section{Stall Speed Requirement}

The stall speed requirement is set at 60 knots and relates to wing loading, density altitude and maximum lift coefficient as shown in equation (12). Singleengine airplanes have a range of maximum lift coefficients between 1.3 and 1.9 (Roskam 1985a). A density altitude of $10,000 \mathrm{ft}$ is assumed $\left(0.0056 \mathrm{lb} / \mathrm{ft}^{3}\right)$.

$$
V_{\text {stall }}=\left(2 * \frac{W / S}{\rho * C_{\text {Lmax }}}\right)^{\frac{1}{2}}
$$




\section{Takeoff Distance Requirement}

The takeoff distance requirement is

$$
S_{T O}=2500 \mathrm{ft}
$$

Takeoff distance relates to wing loading, power loading, density ratio and maximum lift coefficient as shown in equation (13), using the takeoff parameter defined in equation (14).

$S_{T O}=8.134 \mathrm{TOP}_{23}+0.0149 \mathrm{TOP}_{23}^{2}$

$S_{T O G} \infty\left((W / S)_{T O} * \frac{(W / P)_{T O}}{\sigma * C_{L m a x}}\right)=T O P_{23}$

The density ratio at 10,000 feet is: $\quad \sigma=0.7386$

while the takeoff parameter is (Roskam, part I, 1985):

$T O P_{23}=220 \frac{l b s^{2}}{f t^{2} * h p}$

Hence, the takeoff distance requirement may be expressed as:

$\left(\frac{W}{S}\right)_{T O} * \frac{\left(\frac{W}{P}\right)_{T O}}{C_{L M A X} O}<162 \frac{l b s^{2}}{f t^{2} * h p}$

Landing Distance Requirement

The landing distance requirement is $S_{L}=2000 \mathrm{ft}$ at sea level.

Landing weight is heavier for electric aircraft since battery weight stays the same throughout the flight unlike the reduction in fuel weight in conventional aircraft. Hence:

$W_{L} / W_{T O}=1$

The landing distance relates to stall speed by:

$S_{L}=0.5136 * V_{S L}^{2}$

Relating stall speed to wing loading and maximum lift coefficient yields:

$\frac{2 *(W / S)_{L}}{0.002049 * C_{L \max }}=\left(V_{S} * 1.688\right)^{2}$

from which we get the relationship for the wing loading as a function of the maximum lift coefficient in the landing configuration.

$\left(\frac{W}{S}\right)_{L}=\left(\frac{W}{S}\right)_{T O}=11.36 * C_{\operatorname{Lmax}_{L}}$ 


\section{Drag Polar Estimation}

To size the aircraft according to climbing requirements, it is necessary to estimate first the drag polars (Roskam 1985a). The drag coefficient is given by:

$C_{D}=C_{D 0}+\frac{C_{L}^{2}}{\pi * A * e}$

The low speed drag coefficient can be expressed as a function of the equivalent parasite drag area:

$C_{D 0}=f / S$

The equivalent parasite area is estimated from similar aircraft using the takeoff weight as follows:

$\log _{10} f=a+b * \log _{10} S_{\text {wet }}$

where $\mathrm{a}=-2.0458$ and $\mathrm{b}=1.00$

$\log _{10} S_{\text {wet }}=c+d * \log _{10} W_{T O}$

where $c=1.0892$ and $d=0.5147$

From which we get: $\quad S_{w e t}=875 f t^{2}$ and $f=7.9$

Assuming an aspect ratio $\mathrm{A}=10$ and an Oswald efficiency factor $\mathrm{e}=0.85$ for the clean configuration, the drag polars are shown in Table 5.

Table 5. Drag Polars for the Proposed Aircraft

\begin{tabular}{|l|c|c|c|}
\hline Flight Condition & $\begin{array}{c}\text { Zero-Lift Drag } \\
\text { Coefficient }\left(\mathbf{C}_{\mathbf{D} \mathbf{0}}\right)\end{array}$ & $\begin{array}{c}\text { Oswald Efficiency } \\
\text { Factor }(\mathbf{e})\end{array}$ & Drag Polar \\
\hline Clean & 0 & 0.85 & $0.0407+0.0374 C_{L}{ }^{2}$ \\
\hline Takeoff flaps & 0.0165 & 0.80 & $0.0572+0.0397 C_{L}{ }^{2}$ \\
\hline Landing flaps & 0.0615 & 0.75 & $0.1022+0.0424 C_{L}{ }^{2}$ \\
\hline Landing gear & 0.0215 & no effect & $0.1237+0.0424 C_{L}{ }^{2}$ \\
\hline
\end{tabular}

\section{Climb Requirements}

The rate of climb in fpm is expressed as (Roskam 1985a):

$R C=d h / d t=33,000 * R C P$

where the rate-of-climb parameter is given by:

$R C P=\frac{\eta_{p}}{W / P}-\frac{(W / S)^{1 / 2}}{19 * \sigma^{1 / 2} * C_{L}^{3 / 2} / C_{D}}$ 
The airplane must meet the climb requirements under FAR 23.65 and FAR 23.77, as listed below.

FAR 23.65

The minimum rate of climb at sea level must be at least: $\quad$ RC $=300 \mathrm{fpm}$ This gives a rate-of-climb parameter: $\quad \mathrm{RCP}=0.0091 \mathrm{hp} / \mathrm{lbs}$

Using the drag polar for the clean aircraft from Table 5 we get the following relationship between wing loading and power loading:

$208 /\left(2.3+(\mathrm{W} / \mathrm{S})^{1 / 2}\right)=W / P$

The minimum climb gradient for land planes is 1:12. Using:

$C G R P=18.97 * \eta_{p} * \frac{\sigma^{1 / 2}}{(W / P) *(W / S)^{1 / 2}}=\frac{\left\{C G R+(L / D)^{-1}\right\}}{C_{L}^{1 / 2}}$

we get the relationship between wing loading and power loading:

$(W / P) *(W / S)^{1 / 2}=110.3$

FAR 23.77

The climb gradient must be at least: $\quad C G R=1 / 30=0.0333$

from which we get:

$(W / P) *(W / S)^{1 / 2}=113$

\section{Cruise Speed Requirement}

The cruise speed for propeller-driven aircraft is calculated at $70 \%$ to $80 \%$ of total power. At this power setting, the profile drag is higher than the induced drag, which is approximately:

$C_{D_{i}}=0.1 C_{D_{0}}$

Cruise speed is proportional to the power index, defined as:

$V_{c r} \infty I_{p}=\left(\frac{W / S}{\sigma *(W / P)}\right)^{1 / 3}$

For a cruise speed of 150 knots $(172 \mathrm{mph})$ the power index is $I_{p}=1.0$ (Roskam 1985a). Hence equation (33) yields:

$$
\left(\frac{W / S}{\sigma *(W / P)}\right)^{1 / 3}=1
$$


It is now possible to determine the best combination of wing loading and power loading by plotting all requirements in the matching graph, as shown in Figure 10 and assuming appropriate values for the maximum lift coefficients. A clean version of this graph is reproduced in Figure 11. Table 6 summarizes the results from these studies.

Figure 10. Matching Graph for the Proposed Aircraft

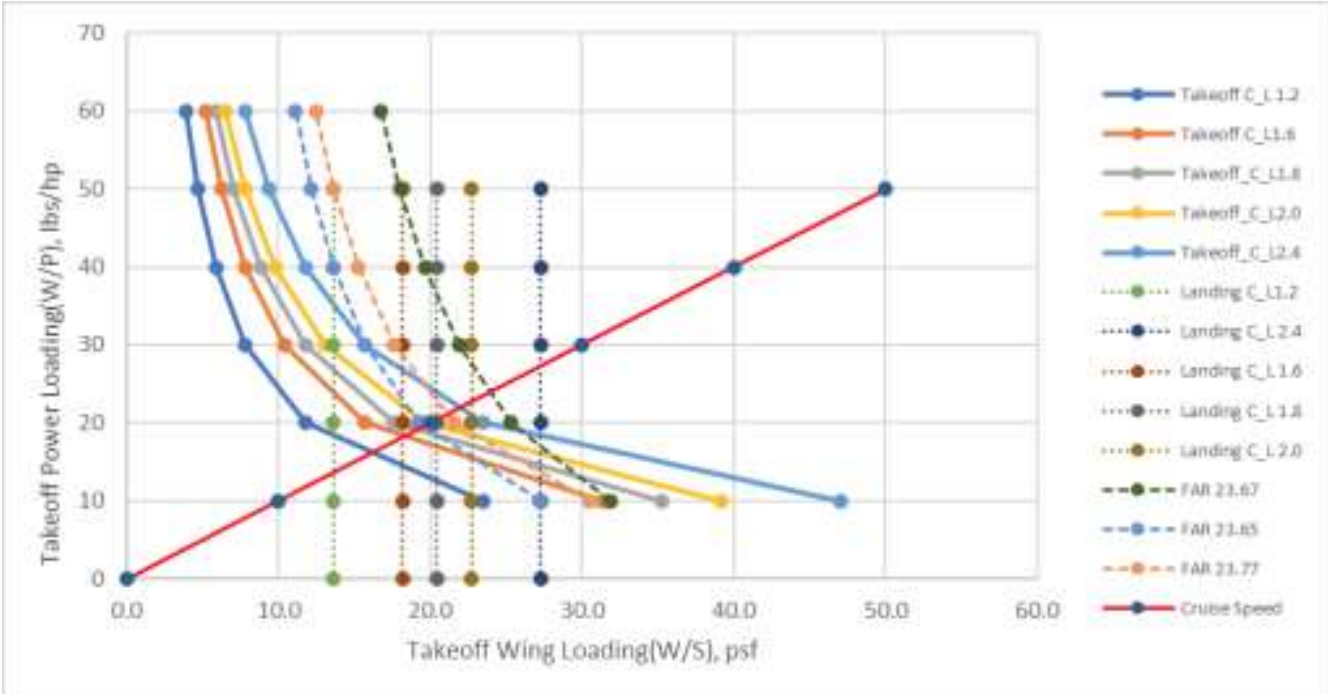

Figure 11. Matching Graph Including only the Three Critical Requirements, which Define the Design Point

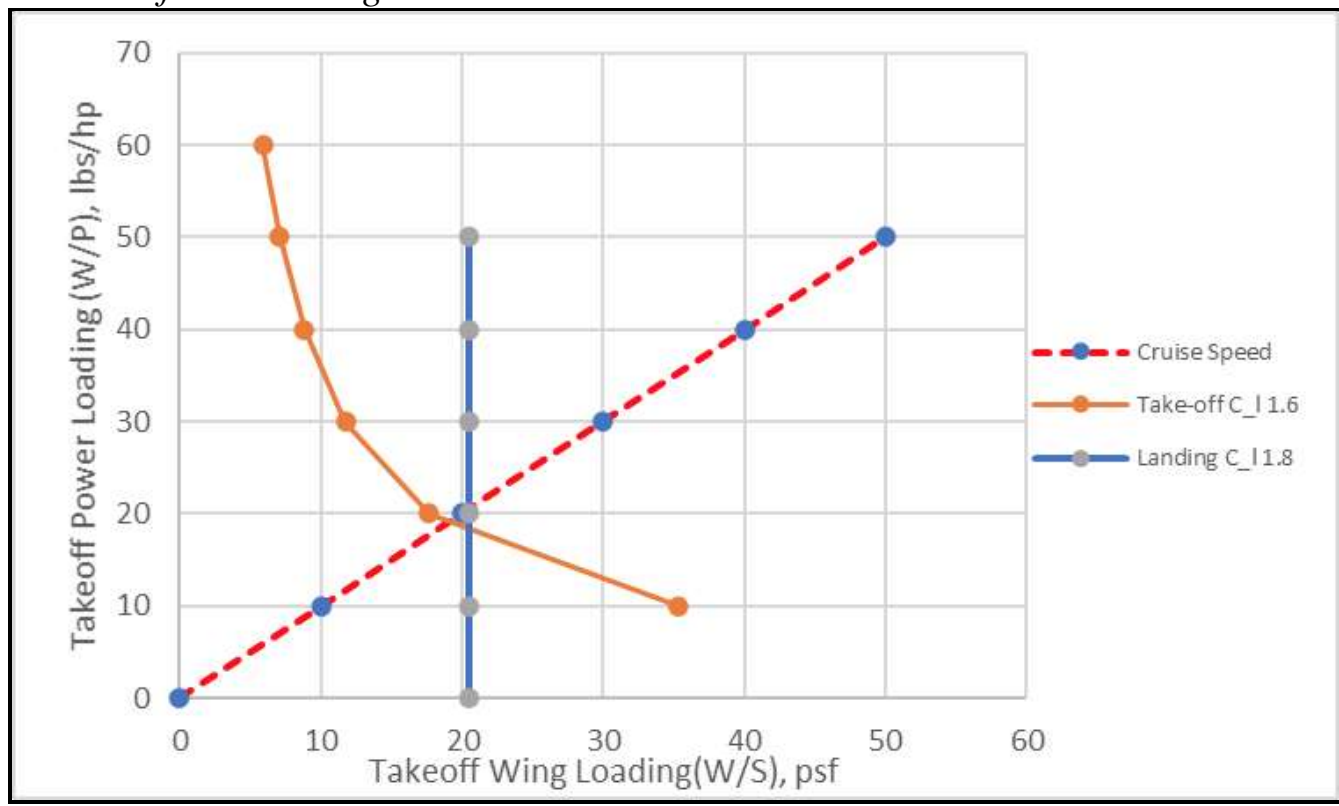

The design point shown in Figure 11 results in a wing loading of $20.5 \mathrm{psf}$ and a power loading of $20 \mathrm{lbs} / \mathrm{hp}$. The various design parameters that correspond to these values are summarized in Table 6. 
Table 6. Design Parameters

\begin{tabular}{|l|c|c|}
\hline \multirow{2}{*}{ Maximum lift coefficient, $\mathrm{C}_{\mathrm{Lmax}}$} & Clean & 1.5 \\
\cline { 2 - 3 } & Takeoff & 1.6 \\
\cline { 2 - 3 } & Landing & 1.8 \\
\hline Aspect ratio & 10 \\
\hline Wing loading, W/S & $20.5 \mathrm{psf}$ \\
\hline Takeoff power loading, (W/P) & & $20 \mathrm{lbs} / \mathrm{hp}$ \\
\hline Wing area, $\mathrm{S}$ & $194 \mathrm{ft}^{2}$ \\
\hline Take-off power, $\mathrm{P}_{\mathrm{TO}}$ & $199 \mathrm{hp}$ \\
\hline
\end{tabular}

\section{Preliminary Design}

The following subsections present the preliminary design of the proposed aircraft (Roskam 1985b).

\section{Configuration}

The proposed configuration is shown in Figure 12. It features a low, cantilever wing with zero sweep for better aerodynamic performance at low speeds. The T-tail was chosen to increase the effective aspect ratio of the vertical stabilizer, while keeping the horizontal stabilizer outside the wing wake. Finally, a conventional tricycle landing gear offers fewer parts, lower weight, lower cost, is easier to design, and most importantly, provides for good ground stability.

Figure 12. Proposed Aircraft Configuration

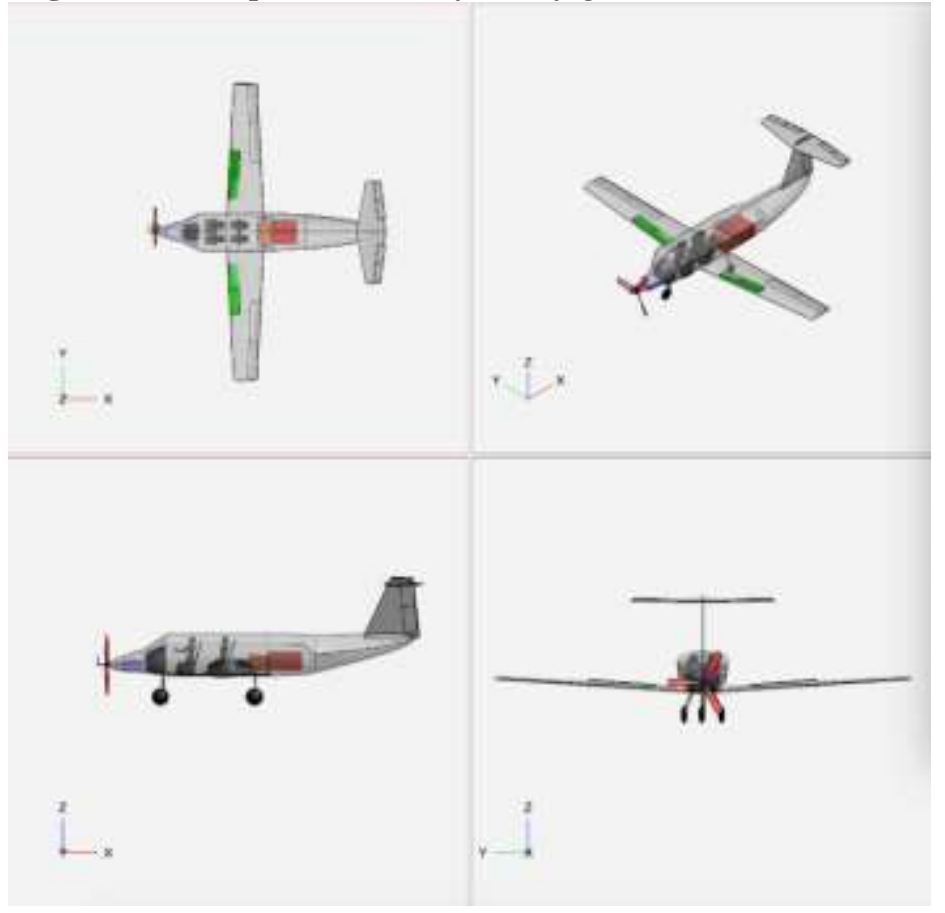




\section{Propulsion System}

The electric engine chosen is a Siemens brushless motor-SP 260D. It features a double winding motor with a $95 \%$ efficiency at $2500 \mathrm{rpm}$ and is lightweight. Energy density, safety, cost, reliability and maintainability were all considered in the selection of rechargeable, lithium-air batteries with an energy density of 1,500 $\mathrm{Wh} / \mathrm{kg}$, expected to be available in 2025 (Hepperle 2012).

The propulsion system is integrated in the fuselage with the electric motor placed at the front and the batteries placed in the wing as well as in the aft fuselage section. The propeller diameter is obtained from equation (35) (Raymer 2012):

$D_{p}=\left(4 * P_{\text {max }} * n_{p} * P_{b l}\right)^{1 / 2}=5.50 \mathrm{ft}$

\section{Fuselage Design}

Fuselage design parameters were calculated using the definitions and aerodynamic considerations in Roskam (1985b) and are shown in Table 7. An isometric view of the fuselage is shown in Figure 13 prepared using the methods and examples in Roskam (1986).

Table 7. Fuselage Design Parameters

\begin{tabular}{|l|c|}
\hline Fuselage Parameters & Dimension \\
\hline Length $\left(l_{f}\right)$ & $29.40 \mathrm{ft}$ \\
\hline Inner diameter $\left(d_{f}\right)$ & $4.5 \mathrm{ft}$ \\
\hline Fineness ratio $\left(l_{f} / d_{f}\right)$ & $6.53 \mathrm{ft}$ \\
\hline Rear fuselage angle $\left(\theta_{f c}\right)$ & $5 \mathrm{deg}$ \\
\hline Cabin length & $10.4 \mathrm{ft}$ \\
\hline Nose length & $5 \mathrm{ft}$ \\
\hline Tail cone length & $14 \mathrm{ft}$ \\
\hline
\end{tabular}

Figure 13. Isometric View of Fuselage

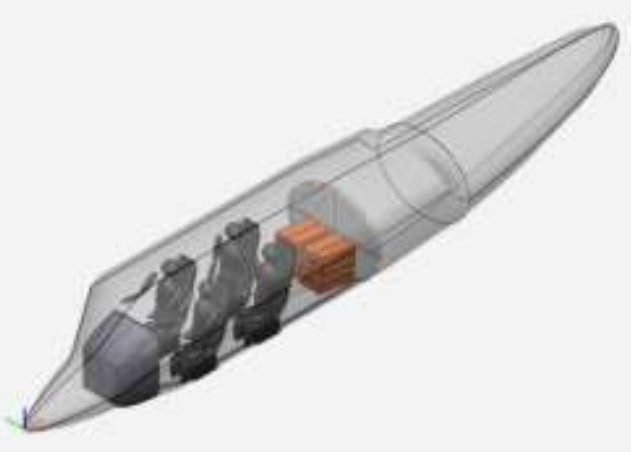


Wing and Lateral Control Surface Design

A NASA LS-0417/13 airfoil is selected because of its superior aerodynamic characteristics (McGhee et al. 1979). From the design wing loading of 20.5 psf, the wing area is:

$S=W_{T O} /(W / S)=194 f t^{2}$

while the wingspan is found from:

$b=\sqrt{A * S}=44 f t$

The root, tip, and mean aerodynamic chords are found as follows:

$c_{r}=2 S /\left(b *\left(1+\lambda_{w}\right)\right.$

$c_{t}=\lambda_{w} * c_{r}$

$\bar{c}=\left(\frac{2}{3}\right) * c_{r} * \frac{1+\lambda_{w}+\lambda_{w}^{2}}{1+\lambda_{w}}$

while the spanwise location of mean aerodynamic chord is given by:

$\bar{y}=\left(\frac{b}{6}\right) * \frac{1+2 \lambda_{w}}{1+\lambda_{w}}$

The wing design parameters are summarized in Table 8 .

Table 8. Wing Design Parameters

\begin{tabular}{|l|c|}
\hline Wing area $(\mathrm{S})$ & $194 \mathrm{ft}^{2}$ \\
\hline Aspect ratio $(\mathrm{A})$ & 10 \\
\hline Wingspan $(\mathrm{b})$ & $44 \mathrm{ft}$ \\
\hline Sweep angle $(\Lambda)$ & $0 \mathrm{deg}$ \\
\hline $\begin{array}{l}\text { Airfoil thickness at the wing centerline } \\
(\mathrm{t} / \mathrm{c})_{\mathrm{r}}\end{array}$ & 0.14 \\
\hline Airfoil thickness at the wing tip $(\mathrm{t} / \mathrm{c})_{\mathrm{t}}$ & 0.12 \\
\hline Taper ratio $(\lambda)$ & 0.50 \\
\hline Dihedral $(\Gamma)$ & $7 \mathrm{deg}$ \\
\hline Root chord $\left(\mathrm{c}_{\mathrm{r}}\right)$ & $5.87 \mathrm{ft}$ \\
\hline Tip chord $\left(\mathrm{c}_{\mathrm{t}}\right)$ & $2.90 \mathrm{ft}$ \\
\hline Mean aerodynamic chord $(\bar{c})$ & $4.57 \mathrm{ft}$ \\
\hline Spanwise location of mac $(\bar{y})$ & $9.75 \mathrm{ft}$ \\
\hline Wing Aerodynamic Center, $\left(\chi_{\mathrm{ac}}\right)$ & $1.14 \mathrm{ft}$ \\
\hline Aileron Chord Ratio $\left(\mathrm{c}_{\mathrm{a}} / \mathrm{c}\right)$ & 0.25 \\
\hline Aileron Span Ratio $\left(\mathrm{b}_{\mathrm{a}} / \mathrm{b}\right)$ & 0.60 \\
\hline
\end{tabular}




\section{Empennage, Directional and Longitudinal Control Surface Design}

The main objective of the horizontal stabilizer is to counter the pitching moments produced by the wing. This must be accomplished, of course, with the smallest possible empennage area. The location of the empennage amounts to estimating the necessary moment arms $x_{v}$ and $x_{h}$, as defined in Roskam (Figure 8.1, 1985b). For the proposed aircraft we find:

$x_{v}=13.5 \mathrm{ft} ; \quad x_{h}=11.5 \mathrm{ft}$

Using the tail volume coefficients, we can now calculate the required area for the horizontal and vertical stabilizers.

$V_{h}=x_{h} *\left(S_{h} /(S * \bar{c})\right)$

$V_{v}=x_{v} *\left(S_{v} /(S * b)\right)$

Assuming $\quad V_{h}=0.50$ and $V_{v}=0.04$

we find $S_{h}=46.25 f t^{2}$ and $S_{v}=26 f t^{2}$

The most important design parameters of the empennage are shown in Table 9.

Table 9. Empennage Design Parameters

\begin{tabular}{|l|c|c|}
\hline Design Parameters & Horizontal Stabilizer & Vertical Stabilizer \\
\hline Aspect Ratio & 5 & 1.6 \\
\hline Taper Ratio & 0.5 & 0.4 \\
\hline Wingspan & $15.20 \mathrm{ft}$ & $6.44 \mathrm{ft}$ \\
\hline Root Chord & $4.05 \mathrm{ft}$ & $5.76 \mathrm{ft}$ \\
\hline Tip Chord & $2.02 \mathrm{ft}$ & $2.3 \mathrm{ft}$ \\
\hline Mean Aerodynamic Chord & $3.15 \mathrm{ft}$ & $4.27 \mathrm{ft}$ \\
\hline Sweep & $10^{\circ}$ & $15^{\circ}$ \\
\hline Airfoil & NACA 0012 & NACA 0012 \\
\hline Dihedral & $0^{\circ}$ & $90^{\circ}$ \\
\hline Incidence & $0^{\circ}$ & $0^{\circ}$ \\
\hline
\end{tabular}

Figure 14. Isometric View of the Empennage with respect to the Wing 


\section{Landing Gear Design \& Weight and Balance Analysis}

To size the landing gear, the center of gravity must first be determined through a weight and balance analysis. Since the weight of the landing gear itself must be included in the weight and balance analysis, an iteration is required to finalize the size and disposition of the landing gear as well as the center of gravity location of the aircraft.

Weight and Balance Analysis

The initial center of gravity location is determined through a Class-I weight fraction analysis of the major subgroups of the aircraft, using the takeoff weight (Roskam 1985b). Each component weight is expressed as a fraction of the takeoff weight $\left(\mathrm{W}_{\mathrm{TO}}\right)$ or the empty weight $\left(\mathrm{W}_{\mathrm{E}}\right)$, as shown in Table 10.

Table 10. Component Weight Fractions for Similar Airplanes and the Proposed Aircraft

\begin{tabular}{|l|c|c|c|c|}
\hline Type & Cessna 210 & Beech J-35 & Cessna 210 J & $\begin{array}{c}\text { Proposed } \\
\text { Electric Aircraft }\end{array}$ \\
\hline Wing Group $/ \mathrm{W}_{\mathrm{TO}}$ & 0.09 & 0.131 & 0.099 & 0.106 \\
\hline $\begin{array}{l}\text { Emp. Group } \\
/ \mathrm{W}_{\mathrm{TO}}\end{array}$ & 0.024 & 0.02 & 0.025 & 0.023 \\
\hline $\begin{array}{l}\text { Fuselage Group } \\
/ \mathrm{W}_{\mathrm{TO}}\end{array}$ & 0.109 & 0.069 & 0.12 & 0.099 \\
\hline $\begin{array}{l}\text { Landing Gear } \\
/ \mathrm{W}_{\mathrm{TO}}\end{array}$ & 0.071 & 0.071 & 0.056 & 0.066 \\
\hline $\begin{array}{l}\text { Fixed equip. } \\
/ \mathrm{W}_{\mathrm{TO}}\end{array}$ & 0.199 & 0.201 & 0.171 & 0.190 \\
\hline $\mathrm{W}_{\mathrm{E}} / \mathrm{W}_{\mathrm{TO}}$ & 0.094 & 0.115 & 0.099 & 0.103 \\
\hline
\end{tabular}

Using the average weight fractions from Table 10, the Class-I component weights are obtained as shown in the second column of Table 11. The mission weights from weight sizing are included in the third column. The sum of the weights in the first column yields an empty weight of $2342 \mathrm{lbs}$, which is slightly lower than the value estimated in weight sizing $(2535 \mathrm{lbs})$. The difference is due to round-off errors in the weight fractions used. This difference is redistributed among all the components in proportion to their weights.

Table 11. Subgroup Component Weight Summary for the Proposed Aircraft

\begin{tabular}{|l|c|c|c|}
\hline Component & $\begin{array}{c}\text { Class-I Estimation } \\
\text { (lbs) }\end{array}$ & Adjustments & Class-I Weight (lbs) \\
\hline Wing & 425 & 35 & 460 \\
\hline Empennage & 92 & 8 & 99 \\
\hline Fuselage & 395 & 33 & 428 \\
\hline Landing Gear & 263 & 22 & 285 \\
\hline Powerplant & 758 & 63 & 821 \\
\hline Fixed Equip. & 409 & 34 & 443 \\
\hline Empty Weight & 2342 & 195 & 2535 \\
\hline Payload & & & 820 \\
\hline Battery Weight & & & 637 \\
\hline Takeoff Weight & & & 3980 \\
\hline
\end{tabular}


The location of the center of gravity for each of the major airplane components is calculated using the geometric definitions in Roskam (Table 10.2, 1985b) (see Table 12).

Table 12. Center of Gravity Location of Major Aircraft Components

\begin{tabular}{|l|c|c|c|c|}
\hline Component & Length (ft) & $\begin{array}{c}\text { cg location } \\
\text { w.r.t. } \\
\text { component } \\
\text { length }\end{array}$ & $\begin{array}{c}\text { cg location } \\
\text { w.r.t. } \\
\text { component } \\
\text { leading } \\
\text { edge/nose (ft) }\end{array}$ & $\begin{array}{c}\text { w.r.t. aircraft } \\
\text { nose (ft) }\end{array}$ \\
\hline Fuselage & 29.4 & $0.39 * l_{f}$ & 11.466 & 11.466 \\
\hline Wing & 4.57 & $0.40 * c_{w}$ & 1.828 & 11.758 \\
\hline $\begin{array}{l}\text { Vertical } \\
\text { Stabilizer }\end{array}$ & 4.27 & $0.30 * c_{v}$ & 1.281 & 26.411 \\
\hline $\begin{array}{l}\text { Horizontal } \\
\text { Stabilizer }\end{array}$ & 2.56 & $0.30 * c_{h}$ & 0.768 & 27.608 \\
\hline $\begin{array}{l}\text { Empty } \\
\text { Weight }\end{array}$ & 29.4 & $0.45 * l_{f}$ & 13.23 & 13.23 \\
\hline
\end{tabular}

Landing Gear Design

The maximum static load per strut is calculated from the following equations:

Nose wheel strut: $P_{n}=W_{T O} * \frac{l_{m}}{\left(l_{m}+l_{n}\right)}=1053 \mathrm{lbs}$

Main wheel strut: $P_{m}=W_{T O} * \frac{l_{n}}{l_{m}+l_{n}} * \frac{1}{n_{s}}=1465 \mathrm{lbs}$

where, $l_{m}=2.7 \mathrm{ft}$ and $l_{n}=7.5 \mathrm{ft}$

where the geometry for the static load on the tricycle gear is defined in Roskam (Figure 9.2a, 1985b). Here $\mathrm{n}_{\mathrm{s}}=2$, as there are two main gear struts. One nose gear strut is used based on the maximum static load calculation. The gear ratios are determined as follows:

$n_{s} * \frac{P_{m}}{W_{T O}}=0.74$, Main gear tire: $D_{t} * b_{t}=16.5 * 6$ inches

$\frac{P_{n}}{W_{T O}}=0.26$, Nose gear tire: $D_{t} * b_{t}=14 * 5$ inches

The general arrangement of the landing gear is determined using two geometric, tip-over criteria:

Longitudinal tip-over criterion

The main landing gear must be behind the aft center of gravity location and the angle between this location and the main landing gear should be 15 degrees as shown in Figure 15. 
Figure 15. Longitudinal Tip-Over Criterion for the Proposed Aircraft

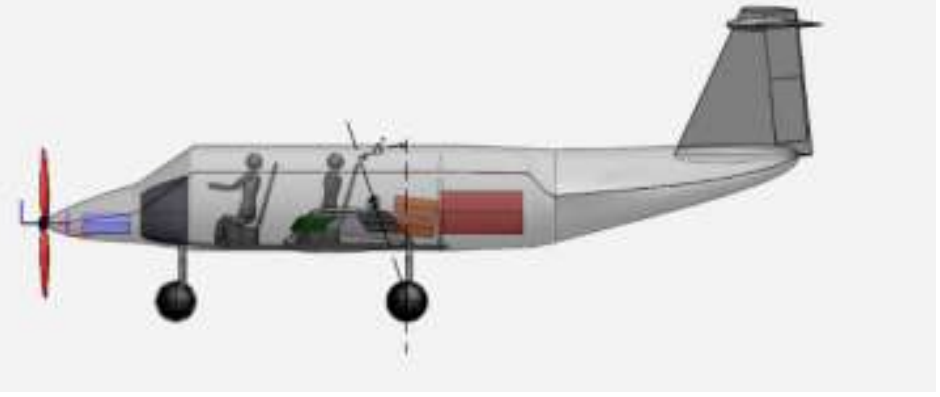

Lateral tip-over criterion

The lateral tip-over criterion (Figure 16) requires that $\psi \leq 55^{0}$.

Figure 16. Lateral Tip-Over Criterion (Roskam 1985b)

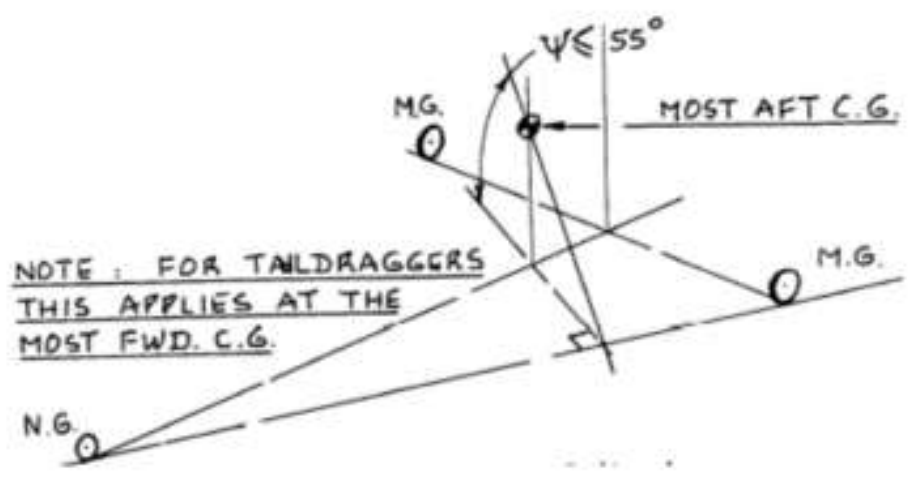

Longitudinal ground clearance criterion

The longitudinal ground clearance criterion requires that the angle defined by the ground contact of the main landing gear and the fuselage tail is greater than the airplane liftoff angle (typically $15^{\circ}$ ). As shown in Figure 17, the proposed configuration clearly exceeds this value.

Figure 17. Longitudinal Ground Clearance Criterion

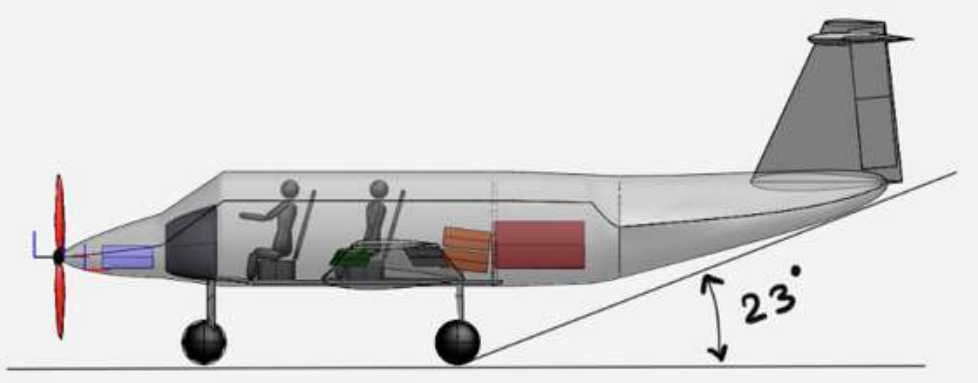


Lateral ground clearance criterion

The lateral ground clearance criterion requires that the angle defined by the ground contact of the main gear and the lowest parts of the wing is at least $5^{0}$ with tires and struts deflated. Figure 18 shows that the proposed configuration exceeds this value.

Figure 18. Lateral Ground Clearance Criterion

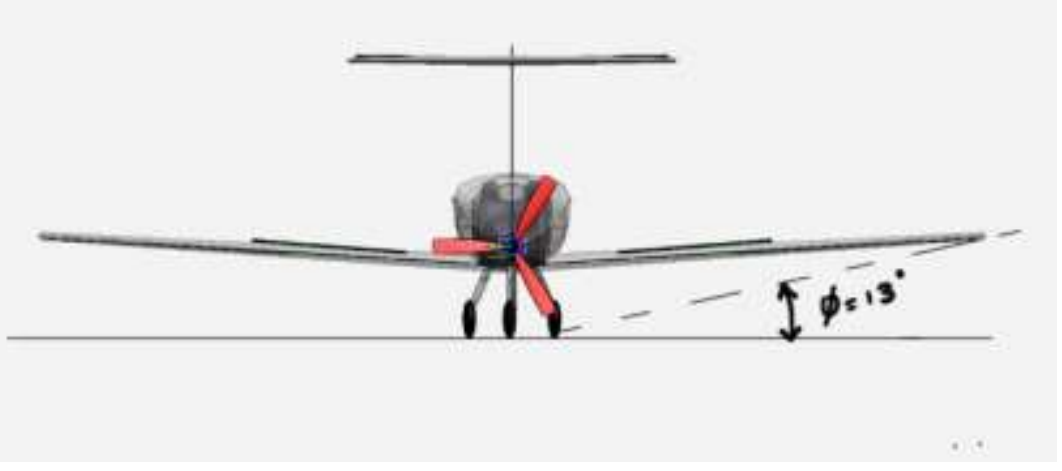

As mentioned earlier, an iterative process is required to determine the disposition of the landing gear, as we need to estimate first the center of gravity location of the airplane, which must include the weight of the landing gear itself. As a result of this process, the main landing gear was moved $1.5 \mathrm{ft}$ forward to meet the two geometric criteria mentioned above. A CAD model of the proposed aircraft configuration is shown in Figure 19.

Figure 19. Center of Gravity Excursion Diagram

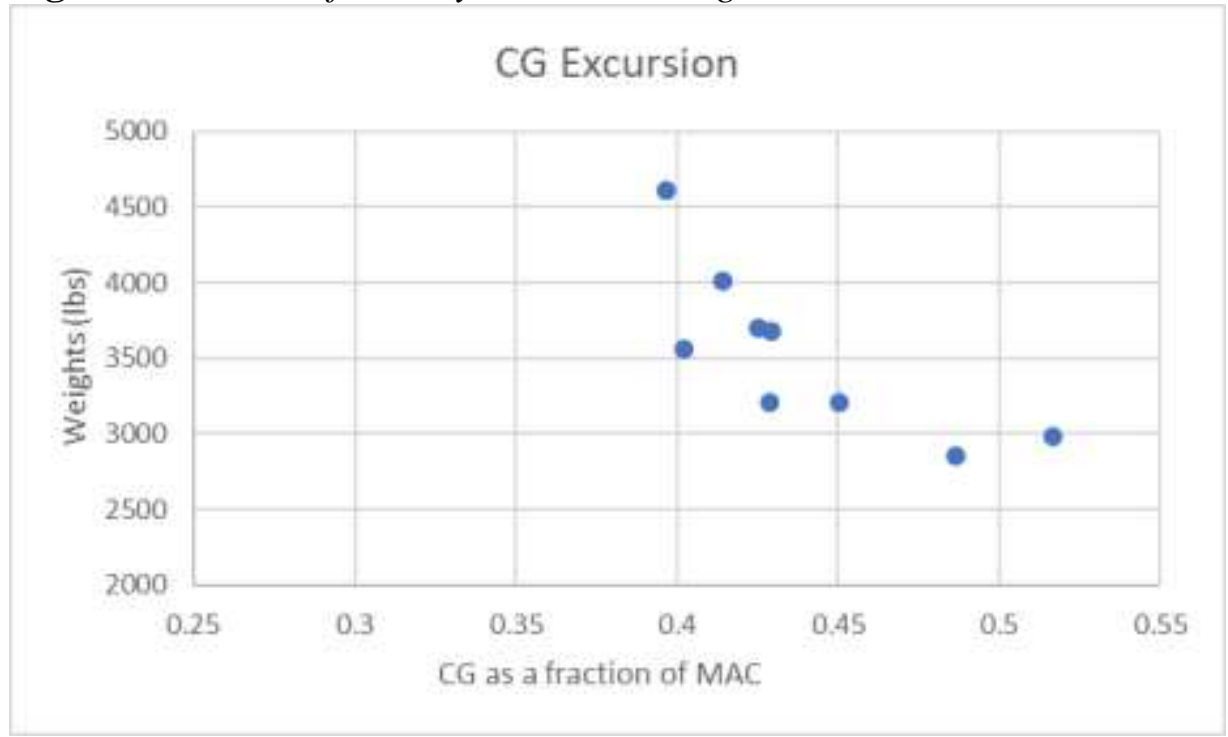


Weight and Balance Analysis

Table 13 shows the component weight breakdown and the center of gravity coordinates of each component, using the final disposition of the landing gear (Roskam 1985c).

Table 13. Component Weights and Center of Gravity Coordinates

\begin{tabular}{|l|c|c|c|c|c|}
\hline $\begin{array}{l}\text { Airplane } \\
\text { Component }\end{array}$ & $\begin{array}{c}\text { Weight } \\
(\boldsymbol{l b s})\end{array}$ & $\begin{array}{c}\boldsymbol{x} \\
(\boldsymbol{f t})\end{array}$ & $\begin{array}{c}\boldsymbol{W} * \boldsymbol{x} \\
(\boldsymbol{f} \boldsymbol{t} * \boldsymbol{l b s})\end{array}$ & $\begin{array}{c}\boldsymbol{Z} \\
(\boldsymbol{f t})\end{array}$ & $\begin{array}{c}\boldsymbol{W} * \boldsymbol{Z} \\
(\boldsymbol{f t} * \boldsymbol{l b s})\end{array}$ \\
\hline Wing & 460 & 11.76 & 5408.68 & 5 & 2300 \\
\hline Empennage & 99 & 27.01 & 2673.94 & 16.4 & 1623.6 \\
\hline Fuselage & 428 & 11.47 & 4907.45 & 6.5 & 2782 \\
\hline $\begin{array}{l}\text { Nose landing } \\
\text { gear }\end{array}$ & 57 & 5.88 & 335.16 & 1.5 & 85.5 \\
\hline $\begin{array}{l}\text { Main landing } \\
\text { gear }\end{array}$ & 228 & 14.70 & 3351.60 & 2.5 & 570 \\
\hline Powerplant & 800 & 4.41 & 3528 & 6 & 4800 \\
\hline $\begin{array}{l}\text { Fixed } \\
\text { equipment }\end{array}$ & 443 & 11.47 & 5079.44 & 6.5 & 2879.5 \\
\hline $\begin{array}{l}\text { Empty } \\
\text { weight }\end{array}$ & 2535 & 13.23 & 33538.05 & 7.38 & 18708.3 \\
\hline $\begin{array}{l}\text { Front row } \\
\text { passengers: }\end{array}$ & 350 & 10 & 3500 & 6.5 & 2275 \\
\hline $\begin{array}{l}\text { Rear row } \\
\text { passengers: }\end{array}$ & 350 & 12 & 4200 & 6.5 & 2275 \\
\hline Luggage & 120 & 15 & 1800 & 6 & 720 \\
\hline Batteries & 620 & 11.758 & 7289.96 & 5.2 & 3224 \\
\hline $\begin{array}{l}\text { Takeoff } \\
\text { Weight }\end{array}$ & & & & & 3872 \\
\hline
\end{tabular}

\section{Center of Gravity Location for Various Loading Scenarios}

Table 14 and Figure 20 show respectively the center of gravity locations and excursion diagram for different loading scenarios.

Table 14. Final Center of Gravity Location for Different Loading Scenarios

\begin{tabular}{|l|c|c|}
\hline Loading scenarios & CG locations from nose (ft) & Weight(lbs) \\
\hline Empty Weight & 13.23 & 2535 \\
\hline $\begin{array}{l}\text { Empty Weight + Front Row } \\
\text { passengers }\end{array}$ & 12.84 & 2885 \\
\hline $\begin{array}{l}\text { Empty Weight + Rear row } \\
\text { passengers }\end{array}$ & 13.08 & 2885 \\
\hline Empty Weight + Passengers & 12.75 & 3235 \\
\hline Empty weight + Baggage & 13.31 & 2655 \\
\hline $\begin{array}{l}\text { Empty Weight + Passengers } \\
+ \text { Baggage }\end{array}$ & 12.83 & 3355 \\
\hline $\begin{array}{l}\text { Empty Weight + Passengers } \\
+ \text { Baggage + Batteries }\end{array}$ & 12.65 & 3872 \\
\hline
\end{tabular}

The center of gravity travel is $0.13 \bar{c}$, well within the acceptable range for single engine propeller-driven aircraft: $0.06 \bar{c}$ and $0.27 \bar{c}$ (Roskam 1985b). The 
most forward and most aft center of gravity locations are $12.64 \mathrm{ft}$ and $13.31 \mathrm{ft}$ respectively from the fuselage nose. The stability and control analysis carried below may require additional iterations to obtain the final center of gravity location of the airplane.

Figure 20. Longitudinal Stability $\chi$-Plot

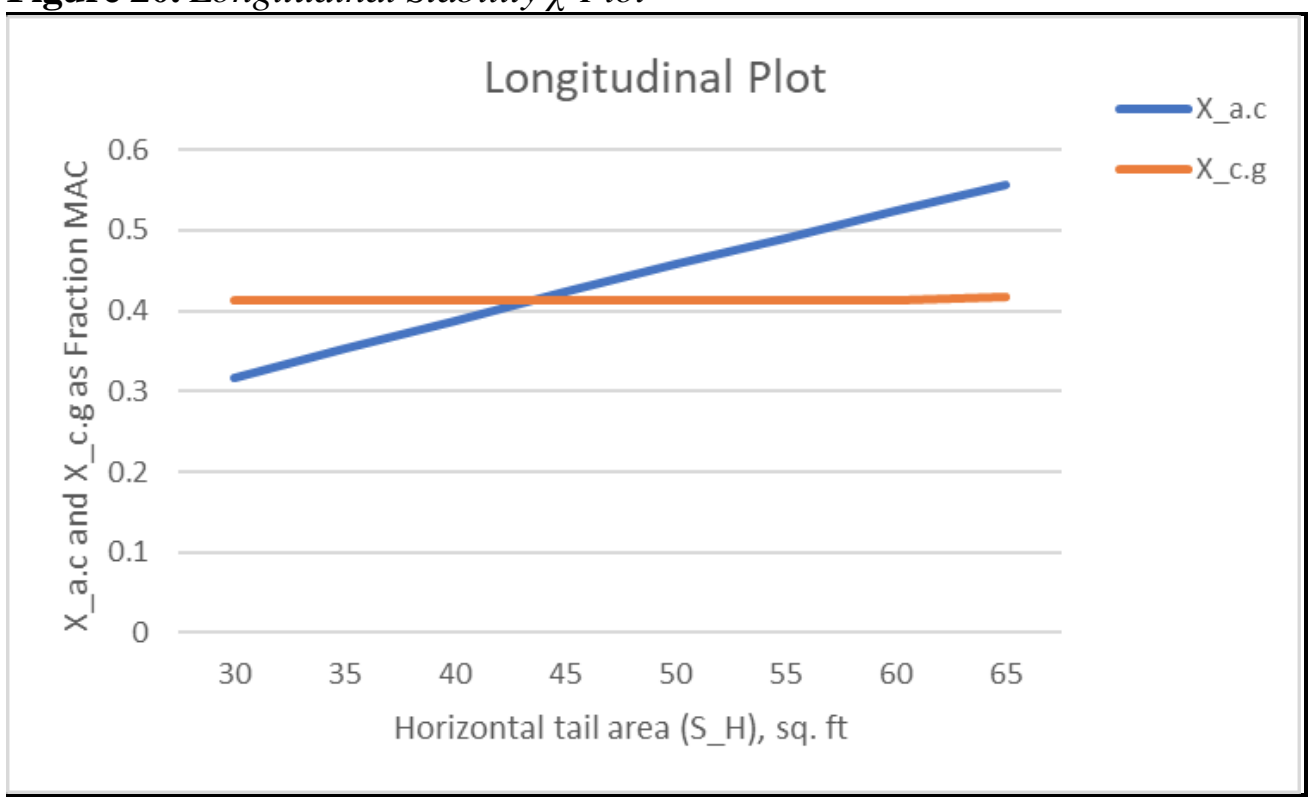

In Figure 20, the horizontal stabilizer area corresponding to the minimum static margin of $5 \%$ is $50.50 \mathrm{ft}^{2}$, while the horizontal stabilizer area obtained through the tail volume coefficient method was $46.25 \mathrm{ft}^{2}$.The difference is within the allowed margins of error for Class-I preliminary design. Hence, the proposed configuration is longitudinally statically stable, and no iteration is required.

\section{Stability and Control Analysis}

The static longitudinal and directional stability of the proposed configuration is established through a Class I stability and control analysis. The longitudinal and directional $\chi$-plots will determine any changes needed in the horizontal and vertical tail areas.

\section{Static Longitudinal Stability}

The two lines in Figure 20 represent respectively the rates at which the center of gravity and the aerodynamic center move as we change the horizontal tail area. The aft center of gravity location was obtained earlier in the weight and balance analysis. The weight of the empennage is known (100 lbs). The horizontal tail weight is $49.95 \mathrm{lbs}$ for a planform area of $46.25 \mathrm{ft}^{2}$. Assuming that the weight of the horizontal stabilizer is independent of surface area, the location of the aerodynamic center is found from equation (49). The longitudinal stability parameters are summarized in Table 15. 


$$
\bar{x}_{a c_{A}}=\frac{X_{a c_{w f}}+\left\{C_{L_{\alpha_{h}}} *\left(1-\frac{d \varepsilon_{h}}{d \alpha}\right) *\left(\frac{S_{h}}{S}\right) * \bar{X}_{a c_{h}}\right\}}{1+\frac{C_{L_{h}}{ }^{*}\left(1-\frac{d \varepsilon_{h}}{d \alpha}\right) *\left(\frac{S_{h}}{S}\right)}{C_{L \alpha_{w f}}}}
$$

Table 15. Static Longitudinal Stability Parameters

\begin{tabular}{|c|c|}
\hline Parameters & Values \\
\hline$x_{a c_{w f}}$ & 0.091 \\
\hline$C_{L_{\alpha_{w f}}}$ & 0.095 per deg \\
\hline$C_{L_{\alpha_{h}}}$ & 0.069 per deg \\
\hline$d \varepsilon_{h} / d \alpha$ & 0.4 \\
\hline$x_{a c_{h}}$ & 3.61 \\
\hline
\end{tabular}

In Figure 21 the $x_{a c}$ and the $x_{c g}$ are plotted as functions of the horizontal tail area, which varies from 0 to $60 \mathrm{ft}^{2}$. The aircraft needs to be inherently stable with a static margin of $5 \%$, hence:

$\frac{d C_{m}}{d C_{L}}=\bar{x}_{c g}-\bar{x}_{a c}=-0.05$

Figure 21. Directional Stability $\chi$-Plot

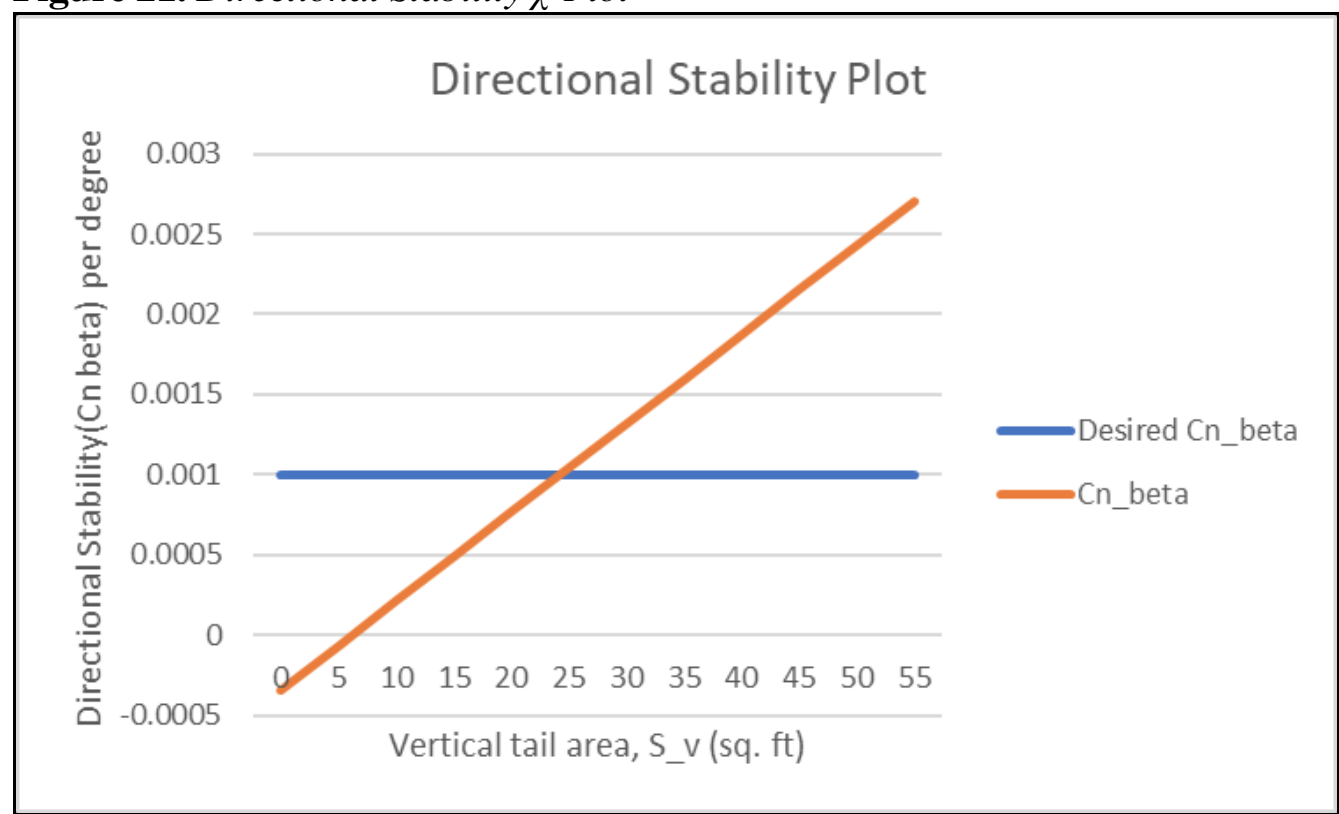

The proposed design is directionally stable with a vertical tail area of $25.2 \mathrm{ft}^{2}$ obtained from Figure 21 at $C_{n}=0.001$. The value obtained from the tail volume coefficient method was $26 \mathrm{ft}^{2}$. The difference between the two values is $3 \%$, which falls within the acceptable limits of accuracy for a Class I preliminary design. 


\section{Directional Stability}

The static directional stability is determined using a directional $\chi$-plot with the side slip moment coefficient plotted as a function of vertical tail area. The $\mathrm{C}_{\mathrm{n} \beta}$ leg of the $\chi$-plot follows from equation (51):

$C_{n_{\beta}}=C_{n_{\beta_{w f}}}+C_{L_{\alpha_{v}}} * \frac{S_{v}}{S} * \frac{X_{v}}{b}$

The wing-fuselage contribution $C_{n_{\beta_{w f}}}$ is calculated from equation (52):

$C_{n_{\beta_{w f}}}=-K_{n} * K_{R I} * S_{f S} *\left(l_{f} / S b\right)$

The static directional stability parameters are shown in Table 16.

Table 16. Static Directional Stability Parameters

\begin{tabular}{|c|c|}
\hline Parameters & Values \\
\hline$C_{n_{\beta_{f}}}$ & -0.000341 per deg \\
\hline$C_{L_{\alpha_{v}}}$ & 0.035 per deg \\
\hline$K_{n}$ & 0.0011 \\
\hline$K_{R I}$ & 1.5 \\
\hline
\end{tabular}

The directional $\chi$-plot of the aircraft is shown in Figure 22.

\section{Drag Polars}

The drag polars were estimated in the performance sizing. The objective of this section is to recalculate these drag polars using the actual geometric characteristics of the airplane.

Airplane Total Wetted Area

The wetted area for the wing, horizontal and vertical tail can be calculated from:

$S_{\text {wet }_{\text {plf }}}=2 * S_{\text {ex }} * 1+\frac{0.25(t / c)_{r} * 1+\lambda \tau}{1+\lambda}$

while the wetted area of the fuselage can be calculated from:

$S_{\text {wetted }_{\text {fuse }}}=\pi * D_{f} * l_{f} *\left(1-\frac{2}{\lambda_{f}}\right)^{\frac{2}{3}} *\left(1+\frac{1}{\lambda^{2}}\right)$

Table 17 shows the wetted areas of the main aircraft components calculated from equations (53) and (54). 
Table 17. Wetted Area of Main Aircraft Components

\begin{tabular}{|l|c|}
\hline Component & Wetted Area $\left(\boldsymbol{f t}^{\mathbf{2}}\right)$ \\
\hline Wing $\left(S_{\text {wet }_{w}}\right)$ & 406.18 \\
\hline Vertical stabilizer $\left(S_{\text {wet }_{v}}\right)$ & 53.56 \\
\hline Horizontal stabilizer $\left(S_{\text {wet }_{h}}\right)$ & 96.28 \\
\hline Fuselage $\left(S_{\text {wet }_{f}}\right)$ & 437.93 \\
\hline Total $\left(S_{\text {wet }}\right)$ & 963.00 \\
\hline
\end{tabular}

\section{Airplane Zero-Lift Drag}

Using the total wetted area from Table 19 in Figure 5.20 of Roskam (1987) the equivalent parasite area of the airplane is:

$f=9 f t^{2}$

from which we can calculate the zero-lift drag coefficient:

$C_{D_{0}}=f / S=0.046$

\section{Low Speed Drag Increments}

Using the drag increments due to flaps and the landing gear for the takeoff and landing configurations from Table 5, the revised drag polars for various flight configurations are shown in Table 18 and plotted in Figure 22. Table 19 compares the lift-to-drag ratios assumed in preliminary sizing with those calculated through the actual drag polars of the aircraft. The difference in values is within $5 \%$, hence resizing of the aircraft is not necessary.

Table 18. Airplane Drag Polars

\begin{tabular}{|l|c|}
\hline Flight Condition & $\mathbf{C}_{\mathbf{D}}$ \\
\hline Clean & $0.0460+0.0374 C_{L}{ }^{2}$ \\
\hline Takeoff flaps & $0.0625+0.0397 C_{L}{ }^{2}$ \\
\hline Landing flaps & $0.1075+0.0424 C_{L}{ }^{2}$ \\
\hline Landing gear & $0.1290+0.0424 C_{L}{ }^{2}$ \\
\hline
\end{tabular}

Table 19. Comparison of the Lift-to-Drag Ratios from Preliminary Sizing (Assumed) and Preliminary Design (Calculated)

\begin{tabular}{|l|c|c|c|}
\hline Flight Condition & $\begin{array}{c}\text { L/D } \\
\text { (preliminary sizing) }\end{array}$ & $\begin{array}{c}\text { L/D } \\
\text { (preliminary design) }\end{array}$ & Difference \\
\hline Cruise & 11.72 & 11.50 & $2 \%$ \\
\hline Takeoff & 10.0 & 9.70 & $3 \%$ \\
\hline Landing & 7.50 & 7.35 & $2 \%$ \\
\hline
\end{tabular}


Figure 22. Drag Polars for Cruise, Takeoff and Landing Configurations

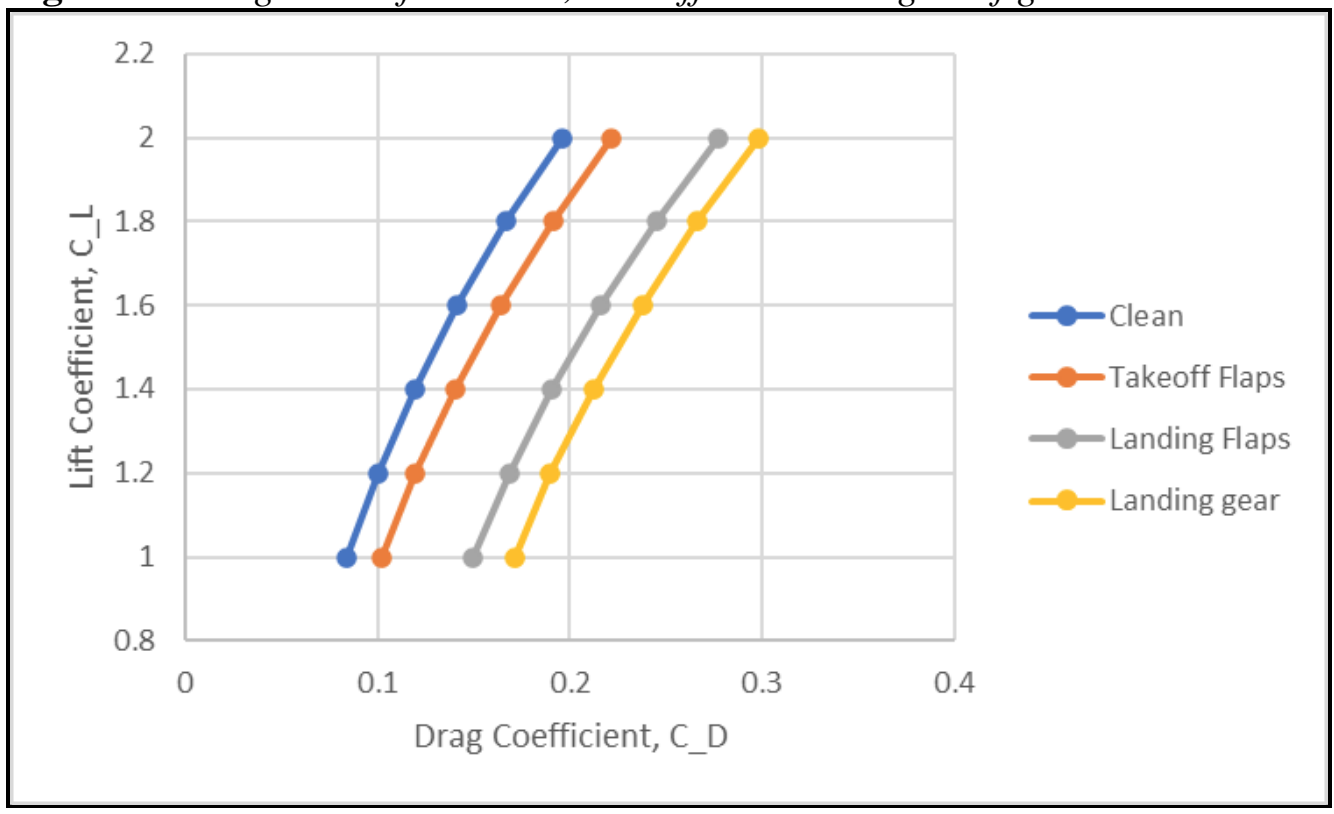

\section{Environmental and Safety Considerations}

The environmental issue associated with the proposed design is the use of lithium- $\mathrm{O}_{2}$ batteries in electric design. Even though the electric aircraft requires no fuel and produces less noise than conventional aircraft, it is clearly not a zeroemission aircraft. The process associated with the production of these batteries emits air pollutants that affect air quality and health. Moreover, the lifetime of these batteries is still short and induces battery waste containing toxic or corrosive materials such as lithium. This hazardous waste could pose additional threats to health and the environment if improperly disposed. Rechargeable batteries will address to a large extent the disposal issue.

\section{Conclusions}

The paper demonstrated that a fully electric, four passenger, FAR-23 certifiable, general aviation airplane with a $750 \mathrm{~km}$ range is feasible, assuming an energy density of $1500 \mathrm{Wh} / \mathrm{kg}$. Clearly, it will take significant improvements in battery technology to allow for such an aircraft. Nevertheless, as research continues to push the limits of this technology, it is not unlikely to have these batteries available as early as 2025 . 


\section{References}

Abdel-Hafez A (2012) Power generation and distribution system for a more electric aircraft-a review. In R Agarwal (ed.), Recent Advances in Aircraft Technology, 289308. In Tech.

Airbus. Airbus Vahana. Retrieved from: https://www.airbus.com/innovation/zeroemission/urban-air-mobility/vahana.html. [Accessed 1 September 2020]

Alisport Swiss. Silent Electro 2. Retrieved from: http://www.alisport.com/?product=silent2-electro-2. [Accessed 28 September 2020]

Banke J (2015) Students electrify NASA with future airplane designs. National Aeronautics and Space Administration - NASA.

Bye Aerospace. Retrieved from: https://byeaerospace.com. [Accessed 5 October 2020]

Bye Aerospace. eFlyer4. Wikipedia. Retrieved from: https://en.wikipedia.org/wiki/Bye_ Aerospace_eFlyer_4\#Specifications_(eFlyer_4). [Accessed 28 September 2020]

Extra EA-300. Wikipedia. Retrieved from: https://en.wikipedia.org/wiki/Extra_EA-300. [Accessed 28 September 2020]

Hepperle M (2012) Electric flight-potential and limitations. NATO/OTAN, STO-MPAVT-209.

Lange Antares. Retrieved from: https://en.wikipedia.org/wiki/Lange_Antares. [Accessed 28 September 2020]

McGhee RJ, Beasley WD, Whitcomb RT (1979) NASA low and medium speed airfoil development. NASA TM 78709.

Panthera. Retrieved from: Pipistrel-USA. <https://www.pipistrel-usa.com/panthera/. [Accessed 27 August 2020]

Pipistrel Taurus. Wikipedia. Retrieved from: https://en.wikipedia.org/wiki/Pipistrel _Taurus\#Specifications_(Taurus_M). [Accessed 28 September 2020]

Raymer DP (1992) Aircraft design: a conceptual approach. Washington, District of Columbia: AIAA Education Series.

Riddell A, Ronson S, Counts G, Spenser K (2004) Towards sustainable energy: the current fossil fuel problem and the prospects of geothermal and nuclear power. California, USA: Stanford University.

Roskam J (1985a) Aircraft design part I: preliminary sizing of airplanes. Lawrence, Kansas, USA: DARcorporation.

Roskam J (1985b) Airplane design part II: preliminary configuration design and integration of the propulsion system. Lawrence, Kansas, USA: DARcorporation.

Roskam J (1985c) Airplane design, part V: component weight estimation. Lawrence, Kansas, USA: DARcorporation.

Roskam J (1986) Airplane design, part III: layout design of cockpit, fuselage, wing and empennage: cutaways and inboard profiles. Lawrence, Kansas, USA: DARcorporation.

Roskam J (1987) Airplane design, part VI: preliminary calculation of aerodynamic, thrust and power characteristics. , Lawrence, Kansas, USA: DARcorporation.

Sigler D (2011) Going vintage electrically. Sustainable Skies. Retrieved from: http://sus tainableskies.org/going-vintage-electrically/. [Accessed 28 September 2010]

Sun Flyer. Bye Aerospace. Retrieved from: https://byeaerospace.com/sun-flyer/. [Accessed 24 August 2020]

Taurus Electro. Pipistrel-USA. Retrieved from: https://www.pipistrel-aircraft.com/aircraft /electric-flight/taurus-electro/. [Accessed 1 September 2020]

Yuneek E430. Retrieved from: http://commercial.yuneec.com/about-us. [Accessed 5 October 2020] 
Vol. 8 , No. 2 Chouhan \& Mourtos: Design of a Four-Seat, General Aviation...

Yuneek International E430. Wikipedia. Retrieved from: http://commercial.yuneec.com/ab out-us. [Accessed 5 October 2020] 